\title{
A New Executive Order for Improving Federal Regulation? Deeper and Wider Cost-Benefit Analysis
}

\section{Citation}

Cass R. Sunstein \& Robert W. Hahn, A New Executive Order for Improving Federal Regulation? Deeper and Wider Cost-Benefit Analysis (John M. Olin Program in Law \& Economics Working Paper No. 150, 2002).

\section{Published Version}

http://chicagounbound.uchicago.edu/law_and_economics/10/

\section{Permanent link}

http://nrs.harvard.edu/urn-3:HUL.InstRepos:12795538

\section{Terms of Use}

This article was downloaded from Harvard University's DASH repository, and is made available under the terms and conditions applicable to Other Posted Material, as set forth at http:// nrs.harvard.edu/urn-3:HUL.InstRepos:dash.current.terms-of-use\#LAA

\section{Share Your Story}

The Harvard community has made this article openly available.

Please share how this access benefits you. Submit a story.

\section{Accessibility}




\section{University of Chicago Law School Chicago Unbound}

Coase-Sandor Working Paper Series in Law and

Economics

Coase-Sandor Institute for Law and Economics

2002

\section{A New Executive Order for Improving Federal Regulation? Deeper and Wider Cost-Benefit Analysis}

Cass R. Sunstein

Robert W.Hahn

Follow this and additional works at: http://chicagounbound.uchicago.edu/law_and_economics Part of the Law Commons

\section{Recommended Citation}

Cass R. Sunstein \& Robert W. Hahn, "A New Executive Order for Improving Federal Regulation? Deeper and Wider Cost-Benefit Analysis" (John M. Olin Program in Law and Economics Working Paper No. 150, 2002).

This Working Paper is brought to you for free and open access by the Coase-Sandor Institute for Law and Economics at Chicago Unbound. It has been accepted for inclusion in Coase-Sandor Working Paper Series in Law and Economics by an authorized administrator of Chicago Unbound. For more information, please contact unbound@law.uchicago.edu. 


\section{CHICAGO}

John M. Olin LAW \& ECONOMICS WORKING PAPER No. 150

(2D SERIES)

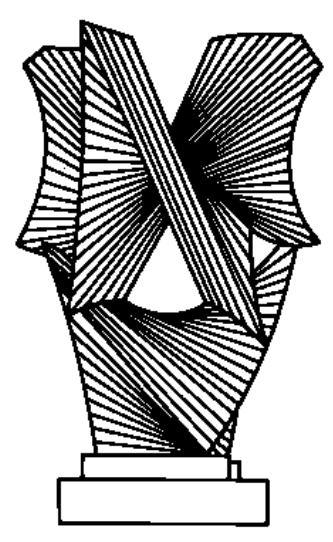

\section{A New Executive Order for Improving Federal Regulation? Deeper and Wider Cost-Benefit Analysis}

Robert W. Hahn and Cass R. Sunstein

THE LAW SCHOOL THE UNIVERSITY OF CHICAGO

This paper can be downloaded without charge at:

The Chicago Working Paper Series Index:

http:/www.law.uchicago.edu/Lawecon/index.html

The Social Science Research Network Electronic Paper Collection:

http://ssrn.com/abstract_id=309754 


\section{A New Executive Order for Improving Federal Regulation? \\ Deeper and Wider Cost-Benefit Analysis}

\section{Robert W. Hahn and Cass R. Sunstein}

\section{Introduction}

\section{A. Processes and Problems}

For over twenty years, the executive branch of the federal government has required regulatory agencies to assess the costs and benefits of regulation, and to attempt to ensure that the benefits outweigh, or justify, the costs. ${ }^{1}$ At least in a formal sense, cost-benefit balancing is now the official creed of the executive branch, as demonstrated by a series of executive orders. ${ }^{2}$ The point cuts across partisan divisions: President Clinton's approach differed somewhat from President Reagan's, but it shared the fundamental commitment to cost-benefit balancing. ${ }^{3}$

Notwithstanding this public commitment, national regulation has hardly come into compliance with the principles of cost-benefit balancing. ${ }^{4}$ This overall pattern of imperfect compliance should raise many alarm bells, even for those who have real doubts about costbenefit analysis and merely want more coherence and better priority-setting. The general record does show numerous successes, in the form of regulations that promise to deliver significant benefits at a relatively low price. ${ }^{5}$ But in many cases, regulations seem to do more harm than good. ${ }^{6}$ Indeed, a close look at federal regulatory policy shows a wide range of problems. Perhaps foremost among them is exceptionally poor priority-setting, with substantial resources

\footnotetext{
${ }^{1}$ President Reagan first issued an executive order requiring agencies to use cost-benefit analysis. See Exec. Order No. 12,291, 3 C.F.R. 127(1982).

${ }^{2}$ See id. (requiring regulations to pass a cost-benefit test); see also Exec. Order No. 12,498, 3 C.F.R. 323 (1986) (requiring agencies to submit an annual regulatory plan and to adhere to cost-benefit principles); Exec. Ord. No. 12,866, 3 C.F.R. 638(1994) (requiring agencies to assess all costs and benefits of regulatory alternatives).

${ }^{3}$ President Clinton's cost-benefit approach expressly required agencies to include qualitative measures of costs and benefits, see Exec. Order No. 12,866, 3 C.F.R. 638, 639 (1994), while President Reagan's approach did not specify which costs and benefits were to be measured, see Exec. Order No. 12,291, 3 C.F.R. 127, 128 (1982).

${ }^{4}$ See Eric Posner, "Controlling Agencies With Cost-Benefit Analysis", University of Chicago Law Review, Vol. 68, no.4, Fall 2001; Robert W. Hahn et al., "Assessing Regulatory Impact Analysis: The Failure of Agencies To Comply With Executive Order 12866", 23 Harvard. J. L \& PP 859 (2000) (suggesting that the absence of information on net benefits in Regulatory Impact Analyses leads to the conclusion that agencies have failed to carry out cost-benefit analyses).

${ }^{5}$ See Robert W. Hahn et al., Do Federal Regulations Reduce Mortality? 15-19 (2000) (evaluating twenty-four regulations whose mortality benefits constitute $90 \%$ of total benefits and concluding that nine pass a cost-benefit test because their net cost per statistical life saved is less than $\$ 5$ million); Cass R. Sunstein, "Cost-Benefit Default Principles", 99 Mich. L. Rev. 1651, 1661 (2001) (providing examples where "cost-benefit analysis has ... led to regulations that accomplish statutory goals at lower cost").
} 
sometimes going to small problems, and with little attention being paid to some serious problems. ${ }^{7}$ There are also unnecessarily high costs, with $\$ 146$ to $\$ 229$ billion being attributable to compliance costs each year. ${ }^{8}$

We do not contend that an assessment of quantified costs and quantified benefits tells us everything that we need to know or that precise numbers are always possible ${ }^{9}$ But when the costs are high and the benefits low or nonexistent, something seems seriously amiss, especially because an absence of significant benefits signals a likely absence of significant savings in terms of health, safety, or the environment. Especially in a period in which economic growth and improved safety and health are among government's highest priorities, this is a major problem. And indeed, the recent reports of the Office of Management and Budget ("OMB"), designed to capture the costs and benefits of a wide range of regulations, reveal some disturbing numbers: the EPA's regulation for financial assurance for municipal solid waste landfills has monetized benefits of $\$ 0$, but costs of $\$ 100$ million, and this is expected for the next thirteen years; ${ }^{10}$ for the next thirteen years, OSHA's methylene chloride regulation will have annual costs of $\$ 100$ million and annual benefits of $\$ 40$ million; ${ }^{11}$ the cost-benefit ratio for airbag depowering regulation seems bad, though there is uncertainty in the data. ${ }^{12}$

Consider Table 1, which lists some estimates of costs and benefits of recent regulations.

\footnotetext{
${ }^{6}$ See Hahn et al., supra note 5, at 23 (finding that over half of the twenty-four regulations studied were likely to cause an increase in mortality risk).

${ }^{7}$ This is the theme of Stephen Breyer' recent book. See Stephen Breyer, Breaking the Vicious Circle: Toward Effective Risk Regulation (1993).

${ }^{8}$ Unless otherwise noted, year dollars are taken from the source that is cited. In this case, OMB estimates that the cost of social regulation as of 1999 is between $\$ 146$ and \$229 billion in 1996 dollars. Office of Management and Budget, Office of Information and Regulatory Affairs, Report to Congress on the Costs and Benefits of Federal Regulations tbl.4 (2000) [hereinafter OMB 2000 Report Charts] http://www.whitehouse.gov/omb/inforeg/2000fedreg-charts.pdf. In an earlier report to Congress, OMB notes that the EPA's Cost of Clean report in 1990 estimated the cost of environmental regulations as of 1988 to be $\$ 101$ billion (1996 dollars). OMB used this figure as a baseline and added the cost of all major environmental regulations issued by the agencies between 1987 and 1996 to estimate the annual cost of environmental regulation in 1997 at $\$ 144$ billion (1996 dollars). Office of Management and Budget, Report to Congress on the Cost and Benefits of Federal Regulation tbl.1 (1997) at http://www.whitehouse.gov/omb/inforeg/chap2.html.

${ }^{9}$ See Kenneth Arrow et al., Benefit-Cost Analysis in Environmental, Health and Safety Regulation 8 (1996) (recommending that analysts "give due consideration to factors that defy quantification but are thought to be important"), available at http://www.aei.brookings.org.publications/books/benefit_cost_analysis.pdf. Lisa Heinzerling and Frank Ackerman, "Pricing the Priceless: Cost-Benefit Analysis of Environmental Protection," $U$. Penn L. Rev.

${ }^{10}$ OMB 2000 Report Charts, supra note 8, tbl.12.

${ }^{11} \mathrm{Id}$.

${ }^{12} \mathrm{Id}$.
} 


\section{Table 1: Questionable Cost-Benefit Ratios ${ }^{13}$ (Net Benefits of Regulations: in millions, adjusted to 1996 dollars)}

\begin{tabular}{|l|l|l|l|l|}
\hline Regulation & $\mathbf{2 0 0 0}$ & $\mathbf{2 0 0 5}$ & $\mathbf{2 0 1 0}$ & $\mathbf{2 0 1 5}$ \\
\hline $\begin{array}{l}\text { Exposure to Methylene } \\
\text { Chloride }\end{array}$ & -60 & -60 & -60 & -60 \\
\hline $\begin{array}{l}\text { Roadway Worker } \\
\text { Protection }\end{array}$ & 0 & 0 & 0 & 0 \\
\hline $\begin{array}{l}\text { Financial Assurance for } \\
\text { Municipal Solid Waste } \\
\text { Landfills }\end{array}$ & -100 & -100 & -100 & -100 \\
\hline $\begin{array}{l}\text { Pulp and Paper Effluent } \\
\text { Guidelines }\end{array}$ & -150 to 0 & -235 to 240 & -840 to 1190 & $-9,200$ to -1000 \\
\hline Ozone Standards & 0 & -40 to 40 & -40 to 40 & -40 to 40 \\
\hline Child Restraint System & -40 to 40 & -220 & -220 & -220 \\
\hline Vessel Response Plans & -220 & -57 to 29 & -57 to 29 & -57 to 29 \\
\hline $\begin{array}{l}\text { Nitrogen Oxide Emission } \\
\text { from new Fossil Fuel } \\
\text { Fired Steam Generating } \\
\text { Units }\end{array}$ & -57 to 29 & & -150 to 0 & \\
\hline
\end{tabular}

It might seem that existing executive orders would prevent or reduce outcomes of this kind, but apparently these orders have not had a large effect. ${ }^{14}$ Indeed, there is some evidence that the existing orders have had little impact on what agencies actually do. ${ }^{15}$

This is no mere academic objection. Expensive regulation may well increase prices, reduce wages, and increase unemployment (and hence poverty). ${ }^{16}$ Resources now being devoted to small or imaginary problems might be diverted instead to areas where, by all accounts, they could produce far more good. Cost-benefit analysis is not an effort to reduce all human goods to

\footnotetext{
${ }^{14}$ See Hahn \& Litan, supra note 13 . Another study suggests that roughly half of the government's final regulations would not pass a cost-benefit test. See Robert W. Hahn, Regulatory Reform: Assessing the Government's Numbers (AEI-Brookings Joint Ctr. for Regulatory Studies, Working Paper No. 99-6, 1999); see also Hahn \& Litan, supra note 13, at tbl.1. (showing that a significant number of recent regulations would fail a strict cost-benefit test).

${ }^{15}$ See Posner, supra note 4. For an examination of the impact of the efficiency effects of the executive orders on regulation, see Scott Farrow, Evaluating the Regulatory Process and Government Performance: Does Executive Office Oversight Matter? (Discussion Paper, Oct. 18, 1999) http://www.epp.cmu.edu/csir/. Farrow finds that executive office oversight does not have a significant efficiency-improving impact on the difference between proposed and final regulations, or on the cost effectiveness of regulation. Id. at 2. A partial reason is that some statutes forbid cost-benefit balancing, but we believe that this is not the whole picture.

${ }^{16}$ To offer a few more details: If regulation increases marginal costs for firms, it is certain to lead to higher prices; if regulation increases a firm's labor costs, wages will be reduced; but it is less clear whether regulation will increase
} 
numbers, but to increase the likelihood that regulation will actually produce human good. According to one study, better allocations of health expenditures could save, each year, 60,000 additional lives at no additional cost-and such allocations could maintain the current level of lives saved with $\$ 31$ billion in annual savings. ${ }^{17} \mathrm{We}$ do not believe that cost-benefit analysis should be the exclusive basis for assessing regulation, but we do believe that it is an important tool, and that a movement toward improved balancing is likely to promote many social goals, including better health and increased longevity. ${ }^{18}$ This somewhat abstract claim has been dramatized by repeated demonstrations that some regulations create significant substitute risks ${ }^{19}-$ -and that with cheaper, more effective tools, regulation could achieve its basic goals while saving billions of dollars. ${ }^{20}$

\section{B. A Deeper and Wider Commitment to Cost-Benefit Analysis}

How can regulation be moved in more sensible directions? This is a large question, and we will not attempt to answer it thoroughly here. But it seems to us that much of the answer lies in improved institutions, and, in particular, in institutional reforms that increase the role of costbenefit analysis in regulatory policy as a way of drawing attention to the likely effects of alternative courses of action. Of course statutory changes would be necessary in many cases. We emphasize two points here. First, the commitment to cost-benefit analysis has been far too superficial, and in some ways mostly symbolic; it should be deepened through efforts to strengthen its actual role. Second, the commitment to cost-benefit analysis has been far too narrow; it should be widened through efforts to incorporate independent regulatory commissions within its reach.

unemployment, at least in the long-run. If the regulation increases the cost of capital relative to labor, employment might even increase.

17 Tammy O. Tengs \& John D. Graham, "The Opportunity of Costs of Haphazard Social Investments" in LifeSaving, in Risks, Costs, and Lives Saved 167-182 (Robert W. Hahn ed., 1996).

${ }^{18}$ See Hahn et al., supra note 5, at 24 (positing that evaluating the mortality implications of regulatory costs is a useful complement to cost-benefit analysis).

${ }^{19}$ See Risk versus Risk: Tradeoffs in Protecting Health and the Environment (John D. Graham \& Jonathan Baert Wiener eds., 1995) (containing case studies demonstrating that risk substitution exists).

${ }^{20}$ See, e.g., A. Denny Ellerman et al., Markets for Clean Air: The U.S. Acid Rain Problem 315 (2000) (stating that the emissions-trading program "can both achieve stated environmental objectives and reduce compliance costs"); Robert N. Stavins, Market-Based Environmental Policies, in Public Policies for Environmental Protection 31, 35-41 (Paul R. Portney \& Robert N. Stavins eds., 2d ed. 2000) (demonstrating that tradable permit programs can achieve environmental goals and save money). 
In this Article, we propose and explore a modest but potentially significant step toward greater depth and width: a new executive order on federal regulation, building on lessons derived from the experience of the last two decades. The proposed order, designed to replace the current one offers eight basic innovations over existing practice. Most of these address the issue of depth; the last point goes to the issue of width.

1. Promoting Compliance. Our proposal attempts to ensure that agencies will actually comply with the basic principles established in previous orders, in part by explicitly requiring agency compliance with OMB guidelines for regulatory analysis. This would be an extremely significant step, because OMB's guidelines have been widely ignored, ${ }^{21}$ and because compliance with those guidelines would significantly increase rationality and coherence in the regulatory process.

2. "Prompting" Regulation. Our proposed order strengthens the role of the Office of Information and Regulatory Affairs ("OIRA") and explicitly creates a mechanism by which OIRA might "prompt" regulation as well as constrain it. This is an important way to ensure that cost-benefit analysis will be used not simply to reduce and limit regulation, but also to spur regulation in those cases where it will do more good than harm. ${ }^{22}$ By creating a mechanism for prompting regulation, our order moves cost-benefit analysis in the direction of service as a technical tool for improving regulation, rather than simply being a mechanism for reducing it.

3. Considering Substitute Risks and Not Regulating Trivial Problems. We include explicit requirements that, to the extent permitted by law, agencies (a) consider the substitute risks introduced by regulation and (b) do not attempt to regulate trivial or de minimis problems. These requirements build on some important developments within the federal courts, which have created default rules authorizing agencies to consider substitute risks and to make de minimis exceptions from regulatory requirements. ${ }^{23}$ These default rules are mirrored in federal

\footnotetext{
${ }^{21}$ See Hahn et al., supra note 4, at 861 (concluding that agencies have ignored OMB guidelines from the fact that RIAs "do not provide enough information to allow regulatory agencies to make decisions that will maximize the efficiency or effectiveness of a rule").

${ }^{22}$ Warren, Edward W., and Gary E. Merchant, "More Good Than Harm: A First Principle for Environmental Agencies and Reviewing Courts." 20 Ecology Law Quarterly 379-440 (1993).

${ }^{23}$ See Sunstein, supra note 5, at 1669-76.
} 
legislation, which often bars regulation of trivial risks, ${ }^{24}$ and which also calls, in many places, for attention to substitute risks. ${ }^{25}$

4. Explaining Rationales for Action When Benefits Do Not Exceed Costs. We require that benefits should generally be expected to exceed costs, and ask agencies to provide a rationale for proceeding with any regulation that fails to pass a cost-benefit test (based on best quantifiable estimates). ${ }^{\mathbf{2 6}}$ Some statutes explicitly require agencies to act even if the benefits fall short of the costs ${ }^{27}$. There may also be cases in which an agency believes that it is worthwhile to proceed even though the quantifiable benefits do not exceed the quantifiable costs. Either way, we believe that accountability and transparency would be enhanced if the head of an agency were required to explain why a regulation is being adopted.

5. Making Underlying Analysis Available. For each significant regulatory action, we ask the appropriate agency to include an underlying analysis of the benefits and costs, so that interested parties inside and outside of the government can understand how the results were obtained, and perform their own analysis of the issue if they so choose. We believe that this requirement will also promote transparency and enhance accountability.

6. Formulating Regulatory Retrospective and Plan._We require each agency to create an annual regulatory retrospective and an annual regulatory plan. The retrospective should contain a general analysis of the costs and benefits of significant regulations; this analysis will facilitate OMB's statutory task of compiling an annual account for the executive branch as a whole. ${ }^{28}$ The annual regulatory plan, following a similar requirement in the existing executive order, ${ }^{29}$ would contain an account of what the agency aspires to do in the following year. The purpose of the regulatory plan is to ensure early, rather than last-minute, OIRA involvement in planning, and also to promote the involvement of high-level agency staff at an early stage.

\footnotetext{
${ }^{24}$ This is the prevailing interpretation of the Occupational Safety and Health Act, under both the toxic substance provisions and the more general provisions of the Act. Indus. Union Dep't, AFL-CIO v. Am. Petroleum Inst., 448 U.S. 607, 639 (1980); Int'l Union, UAW v. OSHA, 37 F.3d 665, 669 (D.C. Cir. 1994).

${ }^{25} 42$ USC $\$ 7411(\mathrm{a})(1)(1994)$.

${ }^{26}$ For a related view, see Robert W. Crandall et al., An Agenda for Federal Regulatory Reform (1997). Crandall et al. recommend that Congress require all regulatory agencies to report the quantifiable and non-quantifiable benefits of regulations. Id. at 12. In addition, the authors argue that "Congress should require that all new regulations costing more than $\$ 100$ million annually pass a broadly defined benefit-cost test." Id. (emphasis omitted).

${ }^{27}$ This could be the case, for example, where a specific performance standard for tailpipe emissions is statutorily set and regulations require automakers to meet that standard regardless of the outcome of a cost-benefit test. See 42 U.S.C. 7409(b)(1).

${ }^{28}$ This task is required by the FY2000 Treasury and General Government Appropriations Act, Pub. L. No. 106-58, § 628(a)), 113 Stat. 472, 472-73 (1996).
} 
7. Incorporating Independent Agencies._For the first time, we include the independent regulatory agencies, such as the Federal Trade Commission ("FTC"), Consumer Product Safety Commission ("CPSC"), and Federal Communications Commission ("FCC"), within the ambit of the order. This is a significant departure from existing practice. We believe that the innovation is justified because these agencies are engaged in particularly important regulatory functions. The inclusion of independent agencies raises obvious legal issues, which we discuss below. ${ }^{30}$

8. Authorizing Judicial Review. We provide for limited judicial review of the documents and materials generated as a result of the order. The goal of this provision is to increase the likelihood that agencies will take the order's requirements seriously. It also authorizes the invalidation of arbitrary and capricious agency action, to the extent that the relevant materials are pertinent, as a matter of law, in a test of the legality of agency conduct.

We believe that a new executive order is probably the best way to move in the directions suggested by these ideas. There are, however, reasonable counterarguments. For well over a year, the Bush Administration has been operating under an executive order issued by President Clinton, and there are real virtues in a situation in which regulatory oversight under a president of one party is done under a set of principles issued by another. It is important to give such oversight both the reality and the appearance of nonpartisanship. A possible approach would be to retain the Clinton order and to issue a supplemental order that embodies some of the proposals described here. In any case many of the ideas in this Essay might be promoted without a new order. Greater depth, at least, might well be achieved simply by a stronger effort, by OIRA, to ensure compliance with existing requirements, ${ }^{31}$ and, indeed, by an insistence on many of the proposals made here. ${ }^{32}$ If a new executive order were not to be issued, considerable progress might well be made with these suggestions in mind. For those who lack enthusiasm for our recommendations, we hope that the discussion will nonetheless cast light on the actual performance of the federal government after twenty years of experience under a (nominal)

\footnotetext{
${ }^{29}$ See infra note 73 (describing the regulatory plan requirement of Executive Order No. 12,866).

${ }^{30}$ See infra Part III.G.

${ }^{31}$ See John D. Graham, "Executive Regulatory Review: Surveying the Record, Making It Work," Address Before the Weidenbaum Center Forum (Dec. 17, 2001),

http://www.whitehouse.gov/omb/inforeg/graham_speech121701.html ("The changes we are making at OMB are not headline-grabbers: No far-reaching legislative initiatives, no rhetoric-laden executive orders, and no campaigns of regulatory relief. Yet we are making some changes that we believe will have a long-lasting impact on the regulatory state.")
} 
commitment to cost-benefit analysis. ${ }^{33}$ Indeed, some critics will be pleased to see the modest effects of cost-benefit requirements to date. ${ }^{34}$

This Article is organized as follows. Part I briefly outlines the development of executive orders on federal regulation. At the same time, it provides an account of what we mean by the still-controversial idea of cost-benefit balancing, and an exploration of the lessons from two decades of experience with executive orders on federal regulation. We emphasize here the extent to which the commitment to cost-benefit analysis has been, too much of the time, symbolic rather than real. Part II explains and defends our innovations. Part III explores the limits of reform via executive order, and offers an account of what else might be done. Following a brief conclusion, the attached Appendix contains the text of our proposed executive order.

\section{Clarifications and Preliminaries}

\section{A. What is Cost-Benefit Analysis?}

Before proceeding to the details, it is important to clarify our basic understanding of costbenefit analysis. We mean to use the term in a modest, nonsectarian way, seeing cost-benefit analysis as a tool and a procedure, rather than as a rigid formula to govern outcomes. ${ }^{35}$ Thus understood, cost-benefit analysis requires a full accounting of the consequences of an action, in both quantitative and qualitative terms. Officials should have this accounting before them when they make decisions.

We do not insist that regulators should be bound by the "bottom-line" numbers; qualitative considerations, and a sense of distributive impacts (not themselves considered "benefits" in the analysis), are permitted to influence public officials. But if regulators are to proceed, they should be prepared to explain either how the benefits exceed the costs, or if they do not, why it is nonetheless worthwhile to go forward. When the benefits do not exceed the costs, it would make sense to adopt a presumption against proceeding - a presumption that might

\footnotetext{
${ }^{32}$ Of course, it would not be possible, without a new executive order, to incorporate the independent regulatory commissions under the process of OIRA review.

${ }^{33}$ We do not deal here with a pervasive problem: OIRA has a small staff (about fifty) and many regulations to review (about 600 are deemed significant each year). To produce the improvements that we think desirable, it would obviously be important to ensure that OIRA's staff is large enough to do the necessary work.

${ }^{34}$ Supra 10.

${ }^{35}$ See Kenneth Arrow et al, supra note 9, at 3 ("Benefit-cost analysis should play an important role in informing the decision making process....") (emphasis added); Matthew D. Adler \&Eric A. Posner, Implementing Cost-Benefit
} 
be rebutted by showing, for example, that children would be the principal beneficiaries of the regulation, or that poor people would be disproportionately benefited. We therefore understand cost-benefit analysis to require a certain procedure: A quantitative and qualitative accounting of the effects of regulation, together with a duty to explain the grounds for action unless the benefits exceed the costs. On this view, the antonym to regulation guided by cost-benefit analysis is regulation undertaken without anything like a clear sense of the likely consequences-or regulation that amounts to a stab in the dark. ${ }^{36}$

What are the arguments for cost-benefit analysis, so understood? We do not attempt to answer this question in detail ${ }^{37}$; but it is important to see the central points. The standard response is economic in character: Regulation should ordinarily promote social welfare, and while social welfare might be promoted by regulations that fail cost-benefit analysis, ${ }^{38}$ costbenefit analysis is an imperfect but useful and administrable proxy for the inquiry into the social welfare question. At the very least, it seems clear that regulation is unlikely to promote social welfare when its costs are very high and its benefits are very low-especially when we consider the fact that high costs are likely to be translated into some combination of higher prices, lower wages, and lower returns to capital. It is not necessary to think that government should be treated as some maximizing machine in order to conclude that officials should know the consequences of regulation before they act, and that they should be reluctant to issue regulations that promise to cost much and to deliver little.

Of course it is possible that in practice, quantitative cost-benefit analysis will have excessive influence on government decisions, drowning out "soft variables." Since the numbers are not all that matters, any such effect would be a point against cost-benefit analysis. But to date, the actual record does not support this concern. To take just one example, the EPA's

Analysis When Preferences Are Distorted, 29 J. Legal Studies 1105, 1106 (2000) (“CBA is properly conceptualized as a welfarist decision procedure....") (emphasis added).

${ }^{36} \mathrm{We}$ are assuming throughout that regulators are acting in a situation of risk (where probabilities can be assigned to various outcomes) rather than uncertainty (where no such probabilities can be assigned). In a situation of uncertainty, when existing knowledge does not permit regulators to assign probabilities to outcome other decision rules may be useful, because it is exceedingly hard to do cost-benefit analysis. In such circumstances, the maximin principle could be used (choose the policy with the best worst-case outcome). See Jon Elster, Explaining Technical Change 185-207 (1983), for a helpful discussion.

${ }^{37}$ For a discussion of the value of cost-benefit analysis, see Arrow et al, supra note 9, at 3-6; Cass R. Sunstein, Risk and Reason (Cambridge University Press, forthcoming 2002).

${ }^{38}$ See Matthew D. Adler \& Eric A. Posner, "Rethinking Cost-Benefit Analysis," 109 Yale L.J. 165, 245-46 (1999) (stating that "maximizing overall well-being is an important role of the government" and providing examples of situations where the outcome of cost-benefit analysis should be disregarded in favor of welfarist considerations). 
decision to go forward with new controls on arsenic in drinking water was supported partly on the ground that nonquantifiable variables tipped the balance. We will suggest that in appropriate cases, distributional considerations should also count. The risk that cost-benefit analysis will drown out relevant variables is not a reason to abandon the analysis, but to take steps to ensure against any such effect.

It is useful to compare cost-benefit analysis with the "precautionary principle," often invoked as a foundation for risk regulation and indeed as an alternative to cost-benefit analysis. ${ }^{39}$ The precautionary principle asks government to prevent risks, even if they are quite speculative, on the ground that it is important to guard against large problems even if they might not come to fruition. Of course it is worthwhile to take some precautions against serious risks, even if the probability of their occurrence is well under $100 \%$. We think, however, that the precautionary principle is an inadequate guide to action, simply because dangers often lie on both sides of the equation. ${ }^{40}$ Consider the case of genetic modification of food, a process that does carry some risks: A failure to allow genetic modification might well result in many deaths, and a small probability of many more, simply because genetic modification might well deliver cheaper and healthier food. ${ }^{41}$ Doesn't the precautionary principle require genetic modification of food at least as much as it prohibits it?

Or consider the question whether to ban the use of DDT. The precautionary principle might well seem to require the ban, because DDT imposes health risks for birds and mammals, including human beings. But the ban itself seems to be banned by the principle, because any such ban might lead to either unsafe or more expensive substitutes, and in either case the ban creates a

\footnotetext{
${ }^{39}$ See Risk and the Precautionary Principle (Julian Morris ed., 2000).Some suggested alternatives to cost-benefit analysis are nothing of the kind. For example, Lisa Heinzerling and Frank Ackerman, Pricing the Priceless: CostBenefit Analysis of Environmental Protection (2002), discuss technology-based regulation and pollution trading as preferable alternatives. Id. at 31. But cost-benefit analysis, far from being an alternative to technology-based regulation, is a tool for assessing what kind of regulation makes best sense. Pollution trading is a low-cost method of bringing about compliance with regulatory goals. But in any trading system, it is necessary to "cap" overall emissions, and cost-benefit analysis is a way of helping to decide on the most sensible cap. Heinzerling and Ackerman are right to say that many "regulatory programs have been a terrific success without using cost-benefit analysis to set pollution limits." Id. at 32. As we have suggested, cost-benefit analysis helps to identify the successes. Our claim is that we could have more successes, and better successes, and fewer failures if we attempted to analyze the consequences first.

${ }^{40}$ See Jonathan Weiner, Precaution in a Multi-Risk World, in The Risk Assessment of Environmental and Human Health Hazards (Dennis D. Paustenbach ed., 2d ed.

${ }^{41}$ Indur Goklany, Applying the Precautionary Principle in a Broader Context, in Risk and the Precautionary Principle, supra note 33, at 189, 207-220.
} 
(speculative) risk of serious harms. ${ }^{42}$ Or consider an effort to introduce stringent regulation of arsenic in drinking water. It is possible to justify the regulation on the ground that low levels of arsenic might create substantial risks; but it is also possible to complain that the expensive regulation (costing, say, $\$ 200$ million) itself creates a risk of mortality effects, a risk that would be forbidden by the precautionary principle. What should government do?

The precautionary principle, taken for all that it is worth, is thus frequently paralyzing: It stands as an obstacle to regulation and to nonregulation, and to everything in between. Of course speculative harms often deserve attention. But we think that too much of the time, the precautionary principle is merely a combination of rhetoric and myopia, having force only when people look at an essentially arbitrary part of the picture, rather than at the whole. A competent cost-benefit analysis takes good account of what is sensible in the precautionary principle, by asking regulators to attend to low-probability risks of significant harms. Cost-benefit analysis subsumes this risk, as it does all others, into the overall assessment of welfare effects of regulation. ${ }^{43}$ Indeed the most sensible understandings of the precautionary principle emphasize the need for an overall assessment, and insist on exploring all of the risks at stake, including lowprobability, potentially catastrophic risks. ${ }^{44}$

A less familiar argument for cost-benefit analysis, growing out of our doubts about the precautionary principle, is cognitive in character. One goal of cost-benefit analysis is to overcome cognitive limitations by ensuring that people have a full, rather than limited, sense of what is at stake. ${ }^{45}$ People often miss the systemic effects of risk regulation; ${ }^{46}$ cost-benefit analysis is a way of putting those effects squarely on-screen. At the same time, cost-benefit analysis helps overcome the problems created by cognitive heuristics that can lead people to misunderstand the magnitude of risks, by allowing an accounting of the actual consequences of

\footnotetext{
${ }^{42}$ See id. at $190-92$.

${ }^{43}$ Obviously, it is impossible to take extra caution (or spend more) on all activities, simply because there is a finite budget constraint at any point in time. For a good overview of the precautionary principle, see Kimberly M. Thompson et al., "Decision-analytic Refinements of the Precautionary Principle," 4 J. of Risk Res. 127 (2001). Some suggested alternatives to cost-benefit analysis are nothing of the kind. For example, Lisa Heinzerling and Frank Ackerman, Pricing the Priceless: Cost Benefit Analysis of Environmental Protection (2002), discuss technologybased regulation and pollution trading as preferable alternatives. Id. at 31 . But cost-benefit analysis, far from being an alternative to technology-based regulation, is a tool for assessing what kind of regulation makes best sense. Pollution trading is a low-cost method of bringing about compliance with regulatory goals. But in any trading system, it is necessary to "cap" overall emissions, and cost-benefit analysis is a way of helping to

${ }^{44}$ See Indur Goklany, The Precautionary Principle (2001).

${ }^{45}$ See Cass R. Sunstein, supra note 36.
} 
current hazards and of the effects of reducing them. ${ }^{47}$ To the extent that people's emotions are getting the better of them, by producing massive concern about small risks, ${ }^{48}$ cost-benefit analysis should help put things in perspective, and at the same time might help to calm popular fears. And if people are indifferent to a risk that is actually quite large, cost-benefit analysis will help to stir them out of their torpor. The result should be to help with cognitive distortions and to produce sensible priority setting.

There are democratic advantages as well. ${ }^{49}$ Interest groups often manipulate policy in their preferred directions, sometimes by exaggerating risks, sometimes by minimizing them, and sometimes by mobilizing public sentiment in their preferred directions. An effort to produce a fair accounting of actual dangers should help to diminish the danger of interest-group manipulation. More generally, cost-benefit analysis should increase the likelihood that citizens generally, and officials in particular, will be informed of what is actually at stake. By itself, this is a large democratic gain.

Of course, interest groups will also try to manipulate the numbers in their preferred directions. Industry will tend to exaggerate the costs and minimize the risks. Public interest groups will do the opposite. A government that attempts to produce cost-benefit analysis will face a formidable task; it is possible that government will lack the information necessary to do this task well. But if there is a degree of accuracy, and if ranges are specified where there is uncertainty, cost-benefit analysis can be seen, not as some antidemocratic effort to tyrannize people with numbers, but instead as an indispensable tool of democratic self-government.

We can go further. Prospective estimates of both costs and benefits often turn out to be wrong. ${ }^{50}$ This is not merely because of interest group pressures. One reason is that officials lack the extensive information that would permit them to take accurate predictions; indeed, the informational demand on agencies is overwhelmingly, especially because technologies change

\footnotetext{
${ }^{46}$ See Dietrich Dorner, The Logic of Failure 1-10 (Rita \& Robert Kimbel, trans. 1996) (introducing ways in which people discount risk and the potential negative consequences that follow).

${ }^{47}$ See Roger Noll \& James Krier, "Some Implications of Cognitive Psychology for Risk Regulation," 19 J. Legal Stud. 747, 762 (1990) (describing how these "pathologies" can affect estimates of risk).

${ }^{48}$ See George Loewenstein et al., Risk As Feelings, 127 Psychol. Bull. 267 (2001).

${ }^{49}$ Cf. Bruce A. Ackerman \& Richard B. Stewart, "Reforming Environmental Law: The Democratic Case for Market Incentives," 13 Colum. J. Env. L. 171, 172-75, 178-90 (1988) (emphasizing the democratic virtues of economic incentives).

${ }^{50}$ See OMB, 1999 Report to Congress, at 40-43.
} 
over time. ${ }^{51}$ An enduring problem for regulatory policy is the absence of precise information on the cost or benefit sides. This point should be taken, not as a criticism of cost-benefit analysis as such, but as a reason for continuous monitoring and updating. ${ }^{52}$ Our emphasis on retrospective analysis and on prompt letters is intended to take account of the frequent inadequacy of prospective estimates.

There are numerous challenges to cost-benefit analysis as a regulatory tool. ${ }^{53} \mathrm{We}$ cannot discuss those challenges in this space. We suspect that many of them are rooted, at bottom, in pragmatic considerations--in a belief that in practice, cost-benefit analysis will be used as an obstacle to desirable regulation. According to some skeptics, the antonym of cost-benefit analysis is not the unguided stab in the dark, but regulatory protection itself. If this were so, the argument for cost-benefit analysis would be greatly weakened. But the evidence does not support this pessimistic prediction; ${ }^{54}$ indeed, cost-benefit analysis has helped to spur regulation, not merely to stop it. ${ }^{55}$ We believe that, in principle, cost-benefit analysis has a great deal of promise, and that when it has been used, it has often made things better rather than worse. ${ }^{56}$ Of course, the case for cost-benefit analysis will depend, in large part, on what people do with it in the future.

\section{B. History}

Since 1980, all three branches of American government have shown increased interest in cost-benefit balancing. ${ }^{57}$ Our emphasis here is on the actions of the executive branch, which has had a longstanding interest in cost-benefit balancing, an interest that cuts across partisan divisions. ${ }^{58}$ A brief historical review will set the stage.

\footnotetext{
${ }^{51}$ See Bradley Karkkainen, "Toward a Smarter NEPA: Monitoring and Managing Government's Environmental Performance," Columbia Law Review (Forthcoming 2002).

${ }^{52}$ See id. (urging a reform of NEPA that would call for careful attention to new information over time).

${ }^{53}$ See Lisa Heinzerling, "Regulatory Costs of Mythic Proportions," 107 Yale L.J. 1981 (1998) (noting that an assessment of the cost-effectiveness of regulating risk is dependent on subjective evaluations of discounting future benefit, risk assessment, and regulatory purpose). see Heinzerling and Ackerman, "Pricing the Priceless," supra 10.

${ }^{54}$ For varying perspectives, see "Economic Analysis at EPA" (Richard Morgenstern ed. 1999); Eric Posner, University of Chicago Law Review, Volume 68, no. 4,(forthcoming 2002).

${ }^{55}$ For a discussion of the role of economic analysis in spurring regulation of lead in gasoline and regulation of CFCs, destructive of the ozone layer, see "Economic Analysis at EPA," supra note 44. See also the discussion of prompt letters, infra Part II.B..

${ }^{56}$ See "Economic Analysis at EPA," supra note 44

${ }^{57}$ Within Congress, see e.g., 5 U.S.C. $§ 1532,1535$ (requiring cost-benefit analyses and explanations for agency actions); within the executive branch, see supra note 2 (noting presidential directives on cost-benefit requirements).

${ }^{58}$ See Cass R. Sunstein, supra note 36, at ch. 1 .
} 
President Nixon inaugurated the process of this general sort as long ago as 1970, with a mechanism for "Quality of Life" reviews of administrative action. ${ }^{59}$ President Carter introduced a similar process with his Regulatory Analysis Review Group, designed to conduct interagency analysis of cost-effectiveness analysis, required for "significant" rules. ${ }^{60}$ But the decisive step came under President Reagan, with the formal creation of a mechanism for OMB review of major regulations.

The most important innovations in President Reagan's Executive Order 12,291 were: (1) a set of substantive principles for all agencies to follow, "to the extent permitted by law," including a commitment to cost-benefit analysis; (2) a requirement that a Regulatory Impact Analysis, including cost-benefit analysis, accompany all "major" rules; and (3) a formal mechanism for $\mathrm{OMB}$ oversight, with a general understanding that $\mathrm{OMB}$ had some (undefined) substantive control over what agencies would actually do. President Reagan considered subjecting the independent agencies to the new order, but ultimately declined to do so, partly because of concerns about legal authority, but mostly because of fears of an adverse congressional reaction. ${ }^{61}$ The independent agencies were asked voluntarily to comply with Executive Order 12,291; all of them declined.

Executive Order 12,291 proved extremely controversial. ${ }^{62}$ Nonetheless, President Reagan expanded on the basic idea four years later with Executive Order 12,498. ${ }^{63}$ That order established a requirement that agencies submit "annual regulatory plans" to OMB for review. The result was an annual publication, the Regulatory Program of the United States, which contains a discussion of all proposed actions that might be either costly or controversial. Executive Order 12,498 served to increase the authority of agency heads over their staffs, by exposing proposals to toplevel review at an early stage. But it also increased the authority of OMB, by allowing OMB supervision over basic plans, and by making it hard for agencies to proceed without OMB preclearance.

\footnotetext{
${ }^{59}$ See Richard R. Nathan, The Plot That Failed and the Administrative Presidency 45-49 (1975).

${ }^{60}$ See Richard H. Pildes \& Cass R. Sunstein, "Reinventing the Regulatory State," 62 U. Chi. L. Rev. 1, 14 (1995).

61 See Peter M. Shane \& Harold H. Bruff, The Law of Presidential Power 355-359 (1988) (describing and questioning the use of the presidential supervisory power with respect to congressional legislation).

${ }^{62}$ See, e.g., Thomas McGarity, Rationalizing Regulation (1990).

633 C.F.R. 323 (1985).
} 
Under President George Bush, the principal innovation was the Council on Competitiveness, chaired by the Vice President. ${ }^{64}$ The Council engaged in occasional review of agency rules, operating as a kind of supervisor of OMB itself. It also set out a number of principles and proposals for regulatory reform. ${ }^{65}$ In essence, however, the Bush Administration followed the basic approach of its predecessor, with OMB review remaining under the two Reagan executive orders.

Cost-benefit balancing had been highly controversial when conducted by Republican administrations. For this reason, it was uncertain whether President Clinton would allow it to continue to play a role within the executive branch. But in a significant and dramatic step, President Clinton endorsed the essential features of the Reagan-Bush orders in his Executive Order $12,866 .{ }^{66}$ The crucial point about Clinton's order is that it accepted the basic commitments of the two Reagan-Bush orders, by requiring agencies to assess both costs and benefits and to proceed only when the latter justified the former. At the same time, President Clinton offered several changes to the Reagan-Bush processes, mainly attempting to create assurances against the fear of industry capture of the system of review. First, he attempted to diminish public concerns about interest-group power over regulation, by providing a process to resolve conflicts and procedures for greater openness. ${ }^{67}$ Second, he included references to "equity," to "distributive impacts," and to qualitative as well as quantitative factors, evidently so as to ensure that agencies could make adjustments in the process of decision, and abandon the cost-benefit assessment where this seems sensible. ${ }^{68}$ Third, President Clinton moved, in a modest but important way, toward including independent agencies within the executive orders. He did so by requiring the participation of the independent agencies within the unified regulatory agenda ${ }^{69}$ and also by requiring independent agencies to submit their proposals for inclusion within the annual

\footnotetext{
${ }^{64}$ See Office of Management and Budget, Regulatory Program of the United States Government, April 1, 1990March 31, 19915 (1990). Another very different innovation that occurred under the first President Bush was the active promotion of market-based approaches for protecting the environment--the most notable example being the acid rain allowance-trading program, which was the crown jewel of the Clean Air Act Amendments of 1990. For an evaluation of this program, see A. Denny Ellerman et al., Markets for Clean Air (2000).

${ }^{65}$ See id.

${ }^{66}$ Id. at (1994).

${ }^{67}$ See id. ]

${ }^{68}$ Id. at

${ }^{69}$ Id., at $\S(4)(b)$.
} 
regulatory plan, allowing the Vice President an opportunity to advise and consult. ${ }^{70}$ We will build on these initiatives here.

Congress has been slower to support efforts to require the balancing of benefits and costs of major regulations. In 1982 the Senate unanimously passed such a law, but it was defeated in the House of Representatives. ${ }^{71}$ Two primary environmental statutes that allowed the balancing of benefits and costs prior to the mid-1990s are the Toxic Substances Control Act ${ }^{72}$ and the Federal Insecticide, Fungicide, and Rodenticide Act. ${ }^{73}$ Recently, Congress has shown greater interest in emphasizing the balancing of benefits and costs. Table 2 reviews recent regulatory reform initiatives, which could help improve regulation and legislation. The table suggests that Congress now shares the concern of the executive branch that the regulatory system is in need of repair and could benefit from more in the way of economic analysis. ${ }^{74}$ All reforms highlighted in the table emphasize a trend towards considering the benefits and costs of regulation, although the effectiveness of the provisions remains unclear. Perhaps because of the politicized nature of the debate over regulatory reform, these reform efforts have come about in a piecemeal fashion, and there is some overlap in the requirements for analysis. ${ }^{75}$

\footnotetext{
${ }^{70}$ Id. at $\S 4(c)$.

${ }^{71}$ Id.

${ }^{72}$ See 15 U.S.C. $\$ 2605$ (a) (1994) (describing an allowed balancing of "risk of injury to health or the environment").

${ }^{73}$ See 7 U.S.C. § 136a (1994) (allowing regulation to prevent unreasonable adverse effects on the environment).

${ }^{74}$ Robert W. Crandall et al., An Agenda for Federal Regulatory Reform 3 (1997) (noting that "recent legislative debates masked a broad consensus among knowledgeable observers on the need for regulatory reform").

${ }^{75}$ There has been some recent interest in Congress in reducing this overlap by establishing a single congressional agency that would have the responsibility for assessing the government regulation. This agency would be similar to the Congressional Budget Office, but it would have responsibility for regulation. In principle, such an agency could help stimulate better analysis and review of agency rules by providing an additional source of information. See Robert W. Hahn \& Robert E. Litan, "Joint Testimony before the Committee on Governmental Affairs," U.S. Senate, "The Regulatory Right-to-Know Act and the Congressional Office of Regulatory Analysis Act," (April 1999) at http://www.aei-brookings.org/publications/testimony/testimony_99_01.pdf.
} 
Table 2: Recent Regulatory Reform Initiatives ${ }^{76}$

\begin{tabular}{|c|c|}
\hline $\begin{array}{l}\text { Unfunded Mandates Reform } \\
\text { Act of } 1995\end{array}$ & $\begin{array}{l}\text { CBO is required to estimate the costs of laws with } \\
\text { new mandates in excess of } \$ 50 \text { million in any one } \\
\text { year on state, local, and tribal governments, and } \\
\text { in excess of } \$ 100 \text { million in any one year on the } \\
\text { private sector. Likewise, an executive branch } \\
\text { agency must prepare a cost-benefit analysis of } \\
\text { regulations with new mandates in excess of } \$ 100 \\
\text { million in any one year on state, local, and tribal } \\
\text { governments or the private sector. The agency is } \\
\text { required to choose the "least costly, most cost- } \\
\text { effective, or least burdensome alternative," unless } \\
\text { the provisions are inconsistent with law or the } \\
\text { head of an agency can explain why such an } \\
\text { alternative was not adopted. }\end{array}$ \\
\hline $\begin{array}{l}\text { Small Business Regulatory Enforcement } \\
\text { Fairness Act of } 1996\end{array}$ & $\begin{array}{l}\text { An agency must submit each final regulation and } \\
\text { the supporting analyses to Congress and the } \\
\text { General Accounting Office. Congress has at least } \\
\text { sixty calendar days to review major regulations } \\
\text { before they can become effective. During that } \\
\text { time, Congress can enact a joint resolution of } \\
\text { disapproval that, if passed and then signed by the } \\
\text { president, would void the regulation. In addition, } \\
\text { strengthened judicial review provisions hold } \\
\text { agencies more accountable for the impacts of } \\
\text { regulations on small entities. }\end{array}$ \\
\hline $\begin{array}{l}\text { Regulatory Accountability Provision of } \\
1996,1997 \text {, and } 1998\end{array}$ & $\begin{array}{l}\text { In separate appropriations legislation in 1996, } \\
1997 \text {, and } 1998 \text {, Congress required the Office of } \\
\text { Management and Budget to submit an assessment } \\
\text { of the annual benefits and costs of all existing } \\
\text { federal regulatory programs to Congress for } 1997 \text {, } \\
1998 \text {, and 2000, respectively. The Office of } \\
\text { Management and Budget already must review } \\
\text { and approve analyses submitted by agencies } \\
\text { estimating the costs and benefits of major }\end{array}$ \\
\hline
\end{tabular}

\footnotetext{
${ }^{76}$ See Robert W. Crandall et al. An Agenda for Federal Regulatory Reform, 10-11 (1997); Robert W. Hahn, The Impact of Economics on Environmental Policy, 39 J. Envtl. Econ. \& Mgmt 375-399 (2000).
} 


\begin{tabular}{|c|c|}
\hline & $\begin{array}{l}\text { proposed rules. The annual report provisions } \\
\text { build on this review process. }\end{array}$ \\
\hline $\begin{array}{l}\text { Pipeline Safety and Partnership } \\
\text { Act of } 1995\end{array}$ & $\begin{array}{l}\text { The Secretary of Transportation must issue a } \\
\text { pipeline standard "only upon a reasoned } \\
\text { determination that the benefits of the intended } \\
\text { standard justify its costs." }\end{array}$ \\
\hline Food Quality Protection Act of 1996 & $\begin{array}{l}\text { This Act eliminates the Delaney Clause for } \\
\text { pesticides that set a zero-tolerance standard for } \\
\text { carcinogens from residues in processed foods. In } \\
\text { setting standards for raw or processed foods, the } \\
\text { EPA will now establish a tolerance level to } \\
\text { ensure "a reasonable certainty of no harm" from } \\
\text { pesticide residues. For pesticide products that } \\
\text { exceed that negligible risk, the EPA may consider } \\
\text { the benefits of the pesticide to justify granting a } \\
\text { tolerance. }\end{array}$ \\
\hline $\begin{array}{l}\text { Safe Drinking Water Act } \\
\text { Amendments of } 1996\end{array}$ & $\begin{array}{l}\text { Under the original act, the maximum contaminant } \\
\text { level (MCL) was to be } \\
\text { set as close to the maximum contaminant level } \\
\text { goal as "feasible." Feasible was defined as using } \\
\text { the best technology available "taking costs into } \\
\text { consideration." Under the new act, the EPA } \\
\text { administrator "shall publish a determination as to } \\
\text { whether the benefits of the MCL justify, or do not } \\
\text { justify, the costs." }\end{array}$ \\
\hline Truth in Regulating Act of 1999 & $\begin{array}{l}\text { Establishes a three-year pilot program under } \\
\text { which individual agency Regulatory Impact } \\
\text { Analyses are subject to independent evaluation by } \\
\text { GAO, upon request by Congress. }\end{array}$ \\
\hline $\begin{array}{l}\text { Biennial Review Provision of the } \\
\text { Telecommunications Act of } 1996 \text {. }\end{array}$ & $\begin{array}{l}\text { Requires Federal Communications Commission: } \\
\text { (1) to review biennially its regulations pertaining } \\
\text { to telecommunications service providers and } \\
\text { broadcast ownership; and (2) to determine } \\
\text { whether economic competition has made those } \\
\text { regulations no longer necessary in the public } \\
\text { interest. }\end{array}$ \\
\hline
\end{tabular}

Courts, too, have shown interest in cost-benefit principles, developing a set of default rules that authorize agencies to minimize costs and maximize benefits, in the face of statutory ambiguity. Consider the following principles, ${ }^{77}$ all with support in the cases. Unless Congress has clearly said otherwise, agencies will be permitted to make de minimis_exceptions to statutory

\footnotetext{
${ }^{77}$ For a more detailed discussion of these principles, see Cass R. Sunstein, "Cost-Benefit Default Principles," 99
} Mich L Rev 1651 (2001). 
requirements by exempting small risks from regulatory controls. ${ }^{78}$ Unless Congress has clearly said otherwise, agencies will be permitted to balance the health risks created by regulation against the health benefits created by regulation. ${ }^{79}$ Unless Congress has clearly said otherwise, agencies will be permitted to take costs into account in issuing regulations. In its current form, this principle means that where statutes are ambiguous, agencies will have the authority to consider costs as well as benefits. ${ }^{80}$ Unless Congress has clearly said otherwise, agencies will be permitted to decline to regulate past the point where regulation would be economically or technologically feasible. ${ }^{81}$ Unless Congress has clearly said otherwise, agencies will be expected to balance costs against benefits in issuing regulations. ${ }^{82}$

These principles give the executive branch a great deal of room to maneuver because they authorize agencies, when so inclined, to move regulation in more cost-beneficial directions. We will draw on some of these principles in the discussion to follow.

\section{The Record}

One of the basic motivations for reforming the regulatory process is that with sensible reforms, regulators should be able to achieve what everyone would consider to be better social outcomes at lower cost. Table 3 provides that motivation by showing the cost per statistical life saved for a number of final regulations at the Environmental Protection Agency from 1986 to 1994. We acknowledge that tables of this kind cannot tell us everything that we need to know about regulation; ${ }^{83}$ but we believe that enormous disparities of this sort are enough to create a

\footnotetext{
${ }^{78}$ See, e.g., Coalition on Sensible Transportation, Inc. v. Dole, 826 F.2d 60, 72 (D.C. Cir. 1987) (noting that, because "[e]valuating environmental effects of major road building projects ... is a long and arduous process," in deciding whether statutory requirements have been met, a court cannot expect "perfection")

${ }^{79}$ This principle appears to underlie American Trucking Ass'n v. EPA, 175 F.3d 1027, 1052 (1999), which states that the "EPA must consider positive identifiable effects of a pollutant's presence in the ambient air in formulating air quality criteria").

${ }^{80}$ Michigan v. EPA, 213 F.3d 663, 678 (D.C. Cir. 2000) («[P]reclusion of cost consideration requires a rather express congressional direction. »).

${ }^{81}$ See Nat'l Res. Def. Council v. EPA, 824 F.2d 1146 (D.C. Cir. 1987) ("Since we cannot discern clear congressional intent to preclude consideration of cost ... the Administrator may consider those factors.")

${ }^{82}$ Competitive Enter. Inst. v. NHTSA, 956 F.2d 321 (D.C. Cir. 1992) (remanding the case to NHTSA to make certain that "[w]hen the government regulates in a way that prices many of its citizens out of access to large-car safety ... the affected citizens at least know that the government has faced up to the meaning of its choice.".

${ }^{83}$ See Lisa Heinzerling, supra note 46, at 1998 (noting that a table calculating the costs of various regulations per life saved "is both over inclusive and under inclusive").
} 
strong presumption of irrationality and incoherence in regulation. In our view, no one has suggested a basis for rebutting that presumption. ${ }^{84}$

\footnotetext{
${ }^{84}$ Indeed, Heinzerling's own revised table suggests considerable irrationality and incoherence. See id. at 2039, tbl.3 (recalculating estimates of the costs of various regulations per life saved). We will not engage Heinzerling's general attack on quantification, which we believe to be a useful tool for assessing regulation and ensuring cross-regulation consistency.
} 
Table 3: Cost of Selected EPA Regulation Per Statistical Life Saved ${ }^{85}$

\begin{tabular}{|c|c|c|}
\hline Environmental Protection Agency Regulation & Year & $\begin{array}{l}\text { Net Cost per Discounted } \\
\text { Statistical Life } \\
\text { (millions of } 2000 \text { dollars) }\end{array}$ \\
\hline Toxicity characteristics to determine hazardous wastes & 1990 & $-9,400$ \\
\hline Underground storage tanks: technical requirements & 1988 & -400 \\
\hline $\begin{array}{l}\text { Asbestos prohibitions: manufacture, importation, } \\
\text { processing and distribution in commerce (total) }\end{array}$ & 1989 & 21 \\
\hline $\begin{array}{l}\text { National primary and secondary water regulations- } \\
\text { Phase II: MCLs for } 38 \text { contaminants }\end{array}$ & 1991 & 28 \\
\hline $\begin{array}{l}\text { Hazardous waste management system-wood } \\
\text { preservatives }\end{array}$ & 1990 & 57 \\
\hline $\begin{array}{l}\text { Sewage sludge use and disposal regulations, } 40 \text { C.F.R. } \\
\text { Part } 503\end{array}$ & 1993 & 215 \\
\hline $\begin{array}{l}\text { Land disposal restrictions for "third third" scheduled } \\
\text { waste }\end{array}$ & 1990 & 215 \\
\hline $\begin{array}{l}\text { Hazardous waste management system: final solvents } \\
\text { and dioxins land disposal restrictions rule }\end{array}$ & 1986 & 226 \\
\hline $\begin{array}{l}\text { Prohibition on land disposal of first third of scheduled } \\
\text { wastes ("second sixth" proposal) }\end{array}$ & 1988 & 452 \\
\hline $\begin{array}{l}\text { Land disposal restrictions, Phase II: universal treatment } \\
\text { standards and treatment standards for organic toxicity, } \\
\text { characteristic wastes, and newly listed wastes }\end{array}$ & 1994 & 1,030 \\
\hline $\begin{array}{l}\text { Drinking water regulations, synthetic organic } \\
\text { chemicals, } \\
\text { Phase V }\end{array}$ & 1992 & 10,800 \\
\hline $\begin{array}{l}\text { Solid waste disposal facility criteria, } 40 \text { C.F.R. Parts } \\
257 \text { and } 258\end{array}$ & 1991 & 40,700 \\
\hline
\end{tabular}

\footnotetext{
${ }^{85}$ Robert W. Hahn, Randall W. Lutter, and Kip Viscusi, Do Federal Regulations Reduce Mortality? (2000) (visited February 11, 2002) http://www.aei-brookings.org/publications/books/hlv.pdf. Numbers updated from 1995 dollars to 2000 dollars.
} 
There are two key points to note from this table. First, the cost per statistical life saved spans an extraordinarily wide range-from $\$ 9$ billion to over $\$ 40$ billion. Second, there are ample opportunities to save more lives at less cost, simply because of these significant differences in the cost per statistical life saved. Taking advantage of these opportunities would require reallocating expenditures away from those regulations that are least cost-effective and toward those regulations that are most cost-effective. ${ }^{86}$ The consensus among those who study this area is that there is great potential to develop regulations that achieve social objectives at lower cost because of the differences in cost-effectiveness among regulations aimed at achieving the same (or similar) objectives. Note that OIRA appears to agree, having urged a number of new initiatives via the new institution of the "prompt letter," taken up below. ${ }^{87}$

Unfortunately, no institution in the federal government now has, as its primary aim, the goal of targeting regulatory expenditures to their best uses. ${ }^{88}$ Instead, the primary instrument used to review the effectiveness of federal regulations is the regulatory oversight required by the executive orders discussed above. For the most part, this oversight occurs on a regulation-byregulation basis. ${ }^{89} \mathrm{OMB}$ 's job consists of meeting with officials and reviewing each Regulatory Impact Analysis ("RIA") that is prepared for economically significant regulations. ${ }^{90}$ Each RIA

\footnotetext{
${ }^{86}$ There is a long literature on this subject. For analysis by one of the first to make this point, see John F. Morrall, A Review of the Record, 10 Reg. Nov./Dec. 1986 at 25-34. For subsequent efforts, see, e.g., Robert W. Hahn, "Regulatory Reform: What do the Government's Numbers Tell Us?", in Risks, Costs, and Lives Saved 208-253 (Robert W. Hahn ed., 1996); Randall Lutter \& John F. Morrall, Health and Health Analysis: A New Way to Evaluate Health and Safety Regulation, 8 J. Risk Uncertainty 43-66 (1994); Tammy O. Tengs \& John D. Graham, "The Opportunity Costs of Haphazard Social Investments," in Life-Saving, in Risks, Costs, and Lives Saved 167-182 (Robert W. Hahn ed., 1996); Indur M. Goklany, Rationing Health Care While Writing Blank Checks for Environmental Hazards, 15 Reg. Summer 1992 at 14. For a critique of this approach, and of Morrall's in particular, see Heinzerling, supra note 46.

${ }^{87}$ See infra at Part II.B.

${ }^{88}$ Stephen Breyer makes this point and suggests "establishment of new career path that would provide a group of civil servants with experience in health and environmental agencies, Congress, and OMB." Breyer, supra note 8, at 60.

${ }^{89}$ Executive Order 12,866 does direct the Vice President to conduct a yearly meeting with agency heads "to seek a common understanding of priorities and to coordinate regulatory efforts to be accomplished in the upcoming year." Executive Order 12866, supra note 3, at Each agency is also required to submit to OMB: a unified regulatory agenda, which describes all regulations under development or review; a regulatory plan, which describes "the most important significant regulatory actions that the agency reasonably expects to issue in proposed or final form in that fiscal year or thereafter." Id..

${ }^{90}$ The Executive Orders require that the RIA be prepared. Agencies generally do such a regulatory analysis for each economically significant rule whose annual impact on the economy exceeds $\$ 100$ million. Typically, the agency proposing the regulation performs the regulatory impact analysis, often with the help of outside consultants. The analysis is supposed to include a statement of the potential need for the proposal, an examination of alternative approaches, an assessment of benefits and costs, the rationale for choosing the proposed regulatory action, and a statement of statutory authority.
} 
provides a rich source of data for examining the costs and benefits of regulation as well as the cost-effectiveness of selected regulations.

How has the process worked in practice? Our basic answer, documented below, is that the process has not worked extremely well. Unfortunately, it is difficult to gauge the effectiveness of federal executive regulatory oversight and the executive orders themselves. The basic problem is that we have very few natural experiments that provide useful information. One of the present authors used a data set and found that the introduction of OIRA did not appear to affect the cost-effectiveness of regulations, contrary to his hypothesis. ${ }^{91} \mathrm{He}$ is reluctant to conclude, however, that OIRA does not have an effect. ${ }^{92}$ Farrow used a similar data set, but included regulations that are rejected as well as those that are finalized. He found that the costeffectiveness of a rule does not have a large impact on the decision to reject or accept that rule. ${ }^{93}$ Farrow argued that this provides evidence that OIRA has not had an impact, at least as measured in terms of improvements in cost-effectiveness for those rules that are accepted. ${ }^{94}$ Eric Posner reaches similar conclusions, urging that cost-benefit review is less a tool for improving regulation than for increasing presidential control over agencies. ${ }^{95}$

Another way of gauging the effectiveness of regulatory oversight is to measure the quality of each RIA itself. The information provided in an RIA is often badly incomplete, and the level of detail and analytical sophistication varies across agencies and types of regulations. ${ }^{96}$ In some cases the most basic information, about both benefits and costs, is missing. Common deficiencies include inadequate consideration of alternatives, poor treatment of uncertainty, incomplete estimation of benefits and costs, as well as various methodological errors. ${ }^{97}$

\footnotetext{
${ }^{91}$ See Robert Hahn, Reviving Regulatory Reform 52 (2000).

${ }^{92}$ One problem with the data is that they do not directly measure any impact that OIRA might have had on changing the cost-effectiveness of particular regulations, which is one of OIRA's important functions. Hahn explains that the insignificance of OIRA's effect on cost-effectiveness may be due to: a lack of data in the pre-OIRA period; the fact that few rules were proposed or finalized following OIRA's creation; and the methodological problem of measuring OIRA's effect on unobservable, but important factors, like other bureaucrats' treatment of potential regulations. Id..

${ }^{93}$ Farrow finds that (the logarithm of) cost-per-life saved is significant but that "it may not be policy significant as cost per life saved must increase by very large amounts in order to change the probability of rejection by a large factor." Farrow, supra note 15, at 22.

${ }^{94}$ Farrow finds that "The suggested impact of OIRA is either not to change or to increase the estimated cost-per-lifesaved between the proposed and final rule," and that in general, OIRA does not impact cost-effectiveness. Id. at 23.

${ }^{95}$ See Posner, supra note 4.

${ }^{96}$ Hahn, supra note 72, at 212-14 (describing the discrepancies in RIAs across agencies); Richard D. Morgenstern \& Marc K. Landy, Economic Analysis: Benefits, Costs, Implications, in Economic Analysis at EPA (Richard D. Morgenstern ed., 1999).

97 Agencies do not always indicate the year in which specified benefits and costs apply. Agencies may show such information only in particular years instead of presenting full streams of benefits and costs. Perhaps most
} 
Moreover, different assumptions are applied across regulations. ${ }^{98}$ Indeed, comprehensive analyses of the RIAs suggest that they lack analytical consistency and that agencies only superficially comply with the requirements in the Reagan and Clinton executive orders. A study of forty-eight major health, safety, and environmental regulations from mid-1996 to mid-1999 provided evidence that agencies generally failed to comply with the executive order and adhere to the OMB guidelines. ${ }^{99}$

From an evaluation of the record on executive regulatory oversight, we conclude that the commitment to cost-benefit analysis is as much symbolic as real. There is not strong evidence that the Executive Orders or the oversight process has made a substantial difference in policy outcomes. Moreover, there is evidence that the cost-benefit analyses included as part of the regulatory oversight process suffer from serious flaws.

\section{Proposed Innovations}

The major goal of our proposed executive order is to deepen and widen the commitment to cost-benefit analysis. We propose to strengthen the role of OIRA, to offer stricter and clearer principles and requirements, and to ensure a more transparent, coherent, and uniform process at the agency level. We also propose to include the independent agencies within the process of OIRA review. As we shall emphasize, an executive order, by itself, will not do a great deal to change the system of regulation. As suggested by the record of the last two decades, everything depends on matters of implementation. But a new order would itself be a strong signal of a new commitment both to cost-benefit balancing and to OIRA; and the suggested innovations would, we believe, hold out considerable promise for improving the situation.

importantly, in many cases the agency did not complete its quantitative analysis of benefits or cost savings. See Hahn, supra note 72 , at 212-14.

${ }^{98}$ For an analysis of the sensitivity of net benefit calculations to discount rate and benefit valuation assumptions, see id. See also Matthew Adler \& Eric Posner, Implementing Cost Benefit Analysis When Preferences are Distorted, in Cost Benefit Analysis 269, 310 (Matthew Adler \& Eric Posner eds., 2001) (listing valuations of life given by various administrative agencies). Agency practices are variable with respect to the discount rate, see id. at 311 , and these variations can create significant differences in otherwise similar rules. Some of the variations are extremely hard to defend.

99 See Hahn et al., supra note 4. In a comprehensive evaluation of a detailed data set, the authors found that agencies' economic analyses typically do not provide enough information to make decisions that will maximize the efficiency or effectiveness of a rule. For a majority of the rules, agencies failed to quantify net benefits, discuss alternatives, or quantify costs and benefits of alternatives.

For OMB guidelines, which comprise a set of principles for improving regulatory analysis and making the regulatory process more transparent, See Office of Management and Budget, Office of Information and Regulatory 


\section{A. Promoting Compliance}

We have seen that the track record on compliance with regulatory oversight requirements is much less than stellar. ${ }^{100}$ There is no simple solution for the compliance problem. Political will on the part of high-level officials is a key component, but even with political will, agencies might be able to act strategically and game the system.

Keeping these points in mind, we offer two suggestions for compliance: First, OMB should issue a modified set of guidelines on how to perform the analysis that is required in the RIA and on how to evaluate that analysis before it is submitted to OMB. If these guidelines are not met, then the proposed regulation should be returned to the agency until the analysis meets OMB's guidelines. Second, for important regulations, OIRA should work with the agency to agree on a set of key assumptions and alternatives to be used in the analysis. ${ }^{101}$ If the terms of this agreement are violated, then OIRA can elect to return the proposed regulation. ${ }^{102}$ In our approach, the guidelines would have a far more prominent place than they now do. For this reason, we think that the guidelines should be subject to public review and comment before they are finalized. The ordinary process, for notice and comment via the Federal Register, should suffice here, as elsewhere. ${ }^{103}$

Affairs. M-00-08, Guidelines to Standardize Measures of Costs and Benefits and the Format of Accounting Statements (2000) available at http:www.whitehouse.gov/omb/inforeg/costbenefitreport1998.pdf.

${ }^{100}$ See General Accounting Office, Regulatory Reform: Agencies Could Improve Development, Documentation, and Clarity of Regulatory Economic Analyses (1998) at http://www.gao.gov/archive/1998/rc98142.pdf (reporting that significant number of agencies' economic analyses "did not incorporate the best practices set forth in OMB's guidance"). For a comparison of state and federal regulatory oversight initiatives, see Robert W. Hahn, State and Federal Regulatory Reform: A Comparative Analysis, 29 J. Legal Studies 873 (2000).

${ }^{101}$ For a discussion of the benefits and drawbacks of early OMB review of regulatory initiatives, see Christopher C. DeMuth \& Douglas H. Ginsburg, "White House Review of Agency Rulemaking," 99 Harv. L. Rev.. 1075, 1080 (1986).

${ }^{102}$ See Richard Belzer, Comments on Draft Report to Congress on the Costs and Benefits of Federal Regulation (2001). Belzer notes that agencies' "regulatory impact analyses fall short in part because OMB's oversight occurs too late to secure timely methodological corrections." Belzer suggests that before work on an RIA begins, agencies should be required to consult with OMB and to agree upon the key assumptions, parameters, and components of the analysis. He suggests that the protocol that is developed should be subject to public comment and review. He does not, however, suggest an enforcement mechanism. One possibility would be for OMB to return a rule if the terms of the agreement are not met. We think this approach should be tried on an experimental basis at first. We are concerned, among other things, how new knowledge could be incorporated into the decision making process. See, e.g., Cass R. Sunstein, "The Arithmetic of Arsenic," Geo. L. J. (forthcoming 2002), and problems associated with our evolving understanding of arsenic.

${ }^{103}$ There are some legal issues here that we will not address in detail. OMB appears to lack the statutory authority to make rules and regulations governing federal regulation. On the other hand, the President has the standard authority, via executive order, to issue binding principles. For a general discussion, see Elena Kagan, "Presidential Administration," 114 Harv. L. Rev. 2245, 2319-2331 (2001). If the President has that authority, he also has the authority to delegate that power to the Director of OMB, at least if he does so expressly via executive order. 
In terms of substance, the most recent guidelines issued by OMB represent a good start, but we would go further. ${ }^{104}$ Specifically, the following steps would increase transparency in the regulatory process and improve the quality of regulatory analysis. With the exception of the last step, we have not listed them in the Executive Order itself, on the theory that they are too specific and detailed to belong there. We believe, however, that OMB should require such steps:

1. Agencies should post each regulatory impact analysis and supporting documents on the Internet before a draft proposed or final regulation can be considered in the regulatory review process;

2. Agency analyses should include a clear, brief executive summary (no more than one page) that contains information on costs, benefits, and technical information, and that says whether the best estimate of quantifiable benefits associated with the regulation is likely to exceed the best estimate of associated costs, and whether it can be expected to maximize net benefits. ${ }^{105}$ A summary of key aspects of the regulation should be included in a table at the beginning of each RIA. ${ }^{106}$ Table 4 provides an example of a summary table. This table could promote accountability by allowing OMB and other interested parties to evaluate how well agencies are doing in reporting different kinds of information.

\footnotetext{
${ }^{104}$ For the most recent OMB guidelines, see Office of Management and Budget, supra note 84. In OMB's draft review on benefits and costs in 1999, several other possible reforms are discussed, including a proposal to ensure that agencies obtain independent, external peer-review of regulatory analyses "in order to identify areas that need improvement and stimulate the development of better estimation techniques more useful for assessing existing regulations." OMB, supra note 84 . This is probably a good idea if the peer reviewers are chosen independently and are motivated to spend the time to do a good job. For some of the problems with peer review, see Linda Cohen \& Robert Hahn, A Solution to Concerns over Public Access to Scientific Data, 285 Science 535 (1999).

${ }^{105}$ Some discussion of the net benefits of reasonable alternatives should also be included. The guidelines currently specify that analyses should "present a summary of the benefit and cost estimates for each alternative and provide a clear statement of the effects in a form that is easily usable by other readers of the rule." Office of Management and Budget, supra note 84 , at 3 .

${ }^{106}$ For an example of a standardized format that could be used to report and summarize regulatory information, see Robert W. Hahn, "How Changes in the Federal Register Can Help Improve Regulatory Accountability," 52 Admin. L. Rev. 927, 951-952 (2000). The regulatory summaries could provide very useful information to OMB in preparing its annual report on regulation. Specifically, it would enable OMB to provide some quantitative analysis of the extent to which various agencies were complying with its guidelines and doing good RIAs. In addition, it would be a good source of information for other parties interested in evaluating the overall impacts of federal regulation.
} 
Table 4

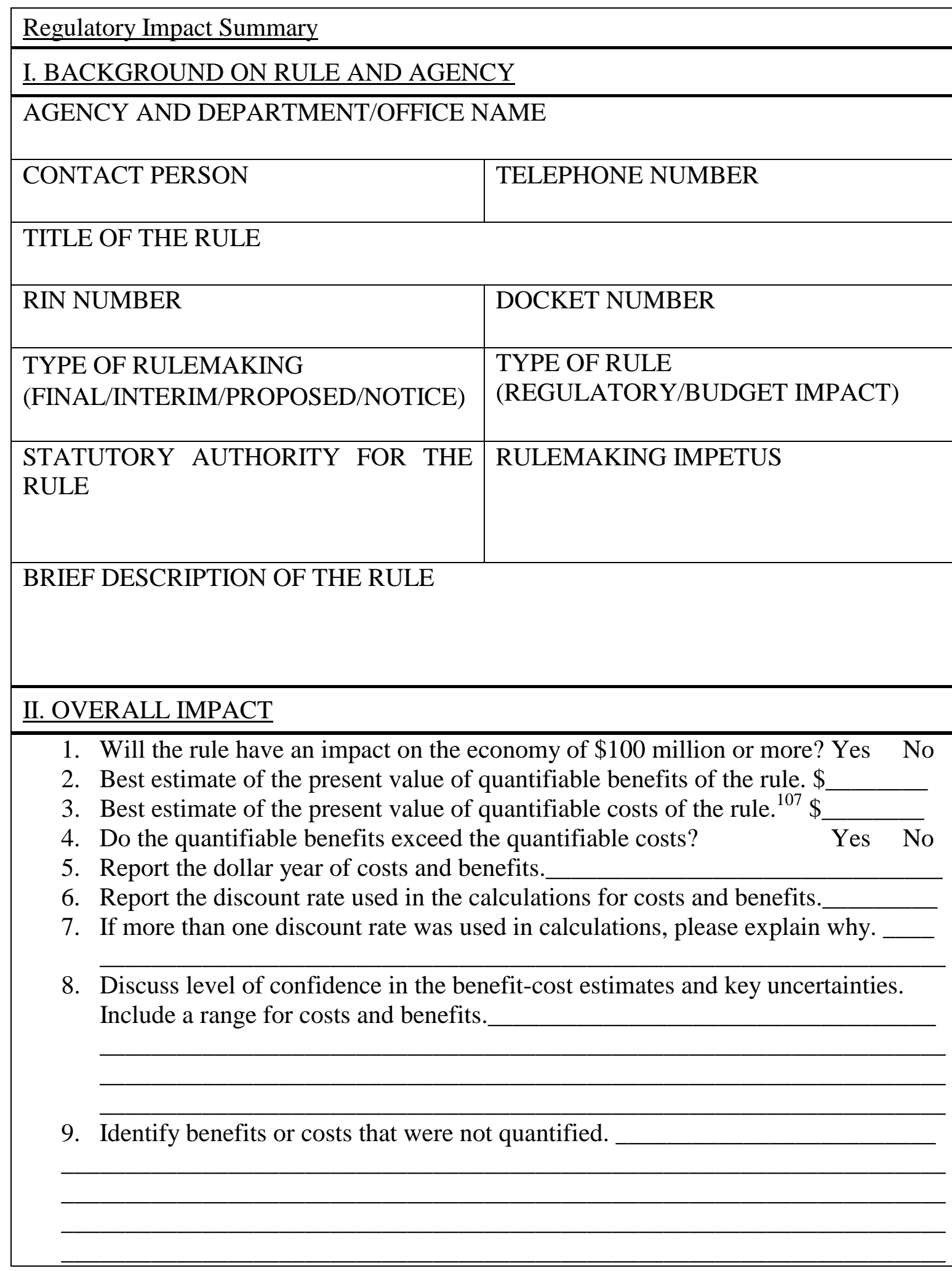

${ }^{107}$ Costs are defined as costs minus cost savings. 


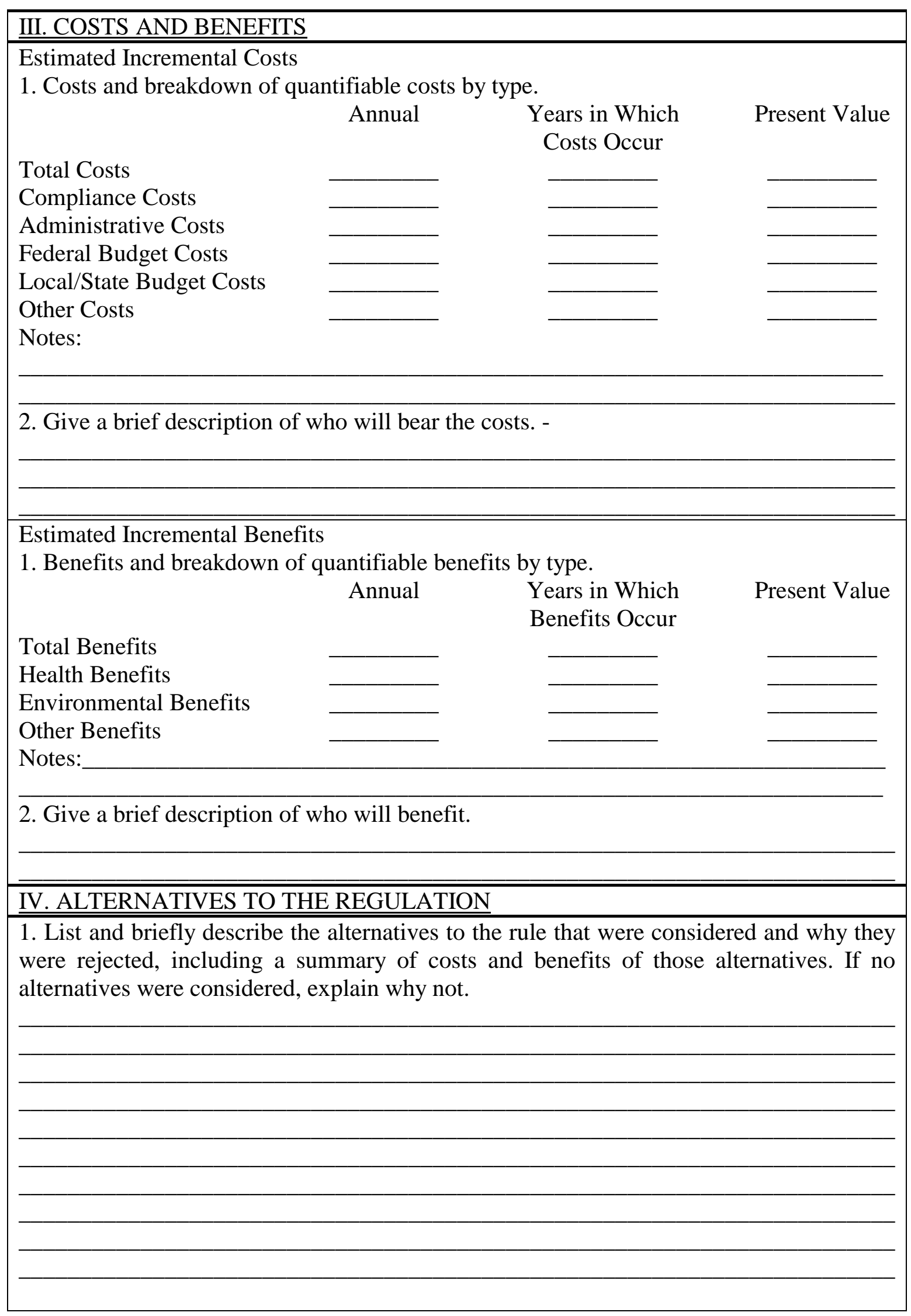


3. Agencies should be required to calculate the net benefits of a regulation based on the best available quantitative information. ${ }^{108}$

4. Agencies should use some default assumptions for standard parameters in order to facilitate comparison within and across regulations. For example, OMB should specify a default discount rate along with a range. Similarly, OMB should specify the value of a quality-adjusted life year and appropriate ranges along with the value of a statistical life and ranges. ${ }^{109} \mathrm{We}$ recognize that these values may, with good reason, differ across different regulations; nonetheless, there is also merit in having a methodology that is fairly standard. Agencies should be permitted to use alternative assumptions where they can provide a good rationale that has a basis in economics. ${ }^{110}$

5. Each federal regulatory agency should be required to produce an annual report on the benefits and costs of regulatory activities. Requiring annual reports would make the regulatory process more transparent, and could improve estimates of the economic impact of regulatory activity. In addition, the agency reports would help the OMB produce its overall assessment of the impact of federal regulation. We add some details below. ${ }^{111}$

\section{B. Prompts and Returns}

Our Executive Order also gives an explicit place for the idea of "prompt letters," an innovation introduced in the early months of the Bush Administration. ${ }^{12}$ To understand this idea, some brief background is in order.

Throughout its history, OIRA's basic mission has been to stop unjustified rules, mainly through the use of "return letters," which require agencies to reconsider their proposals. Yet studies show that adding some regulations, while removing or improving others, could save tens

\footnotetext{
${ }^{108}$ OMB guidelines assume that the agencies will calculate net benefits. They allude to net benefits in discussing the comparison of alternatives in explaining how to discount. They also say that cost-effectiveness can be used instead of net benefit calculations when necessary. The guidelines never say, however, that agencies must calculate net benefits. The sample chart provided by OMB in its guidelines, in which agencies would report summary information about a regulation, includes costs and benefits, but not net benefits. OMB 2000 Report Charts, supra note 8, at 4-5, $7,8,19-20$.

${ }^{109}$ These values could change over time as new knowledge accrues.

${ }^{110}$ Agencies should be required to use the standard assumptions, as well, for ease of comparison across regulations.

111 See infra Appendix, $§ 5$.

${ }^{112}$ See Office of Management and Budget, Prompt Letters, at http://www.whitehouse.gov/omb/inforeg/prompt_letter.html.
} 
of thousands of lives and millions of dollars annually. ${ }^{113}$ An important priority for the future is to redesign existing institutions and agencies by adding regulations that make sense, while reducing those that do not. One of our primary concerns is that no institution in government has yet vindicated the hopes of those who believed that cost-benefit analysis could be used to help promote better priority-setting, block senseless rules, and spur agency action when it is justified.

In 2001, OIRA quietly announced a striking, if overdue, innovation: "prompt letters," designed to encourage agencies to explore new areas in which regulation might deliver benefits that exceed costs. ${ }^{114}$ Not only did OIRA announce the use of prompt letters; it also issued two of them. One of those letters, to the Food and Drug Administration ("FDA"), involved mandatory disclosure of trans-fatty acids in the Nutrition Facts panel of food. ${ }^{115}$ Drawing attention to evidence that trans-fatty acids contribute to coronary heart disease ("CHD”), the letter noted that a disclosure rule seemed to be supported by the FDA's preliminary analysis, which estimated that, ten years after the effective date, the rule would prevent 7,600 to 17,100 cases of CHD and avert 2,500 to 5,600 deaths per year. Over a 20-year period, the FDA estimated the benefits of such a rule would range from $\$ 25$ billion to $\$ 59$ billion, while the costs would be $\$ 400$ million to $\$ 850$ million. The prompt letter strongly encouraged the FDA to issue a disclosure rule or to explain its failure to do so.

The other prompt letter, involving automatic external defibrillators (“AEDs”), was sent to the Occupational Safety and Health Administration, with a firm request that the agency "consider whether promotion of AEDs should be elevated to a priority."116 The letter referred to an editorial in the New England Journal of Medicine, noting that only 2\% to 5\% of the 225,000 persons who have sudden and unexpected cardiac arrest each year outside a hospital are successfully resuscitated compared to the $17 \%$ to $38 \%$ success rates found with AEDs. The prompt letter observed that "some preliminary cost-effectiveness calculations" showed that "AEDs in the workplace might prove to be a very cost-effective intervention." 117 Indeed AEDs, now mandated on air carriers by the Department of Transportation, are estimated to save nine lives per year, at the comparatively low price of $\$ 2.4$ million in annual costs. The prompt letter

\footnotetext{
${ }^{113}$ See supra note $16 .$.

${ }^{114}$ Office of Management and Budget, News Release, at http://www.whitehouse.gov/omb/pubpress/2001-35.html (Sept. 18, 2001)

${ }_{115} \mathrm{Id}$.

${ }^{116} \mathrm{Id}$.

${ }^{117} \mathrm{Id}$.
} 
suggested that OSHA should consider following the Department of Transportation's lead. OIRA has issued a series of prompt letters since the initial announcement, including a letter to the Department of Transportation and the National Highway Traffic Safety Administration regarding frontal offset crash testing, and a letter to the Environmental Protection Agency regarding particulate matter. ${ }^{118}$

In our view, these "prompt letters" are an exceedingly important development. For far too long, the idea of cost-benefit analysis has been wrongly associated with dogmatic opposition to regulation. To be sure, an exploration of costs and benefits often shows that regulation cannot be justified. But cost-benefit analyses can show, and have shown, that government action is worthwhile - and indeed that government should do more. Such analyses helped encourage policymakers to remove lead from gasoline and protect the ozone layer. ${ }^{119}$ Prompt letters promise to strengthen the hand of policy analysts in the federal government, ensuring that action will be taken on the basis of a careful assessment of consequences, rather than in reaction to interest groups or political platitudes.

But why—it might be asked—should prompt letters be made public? Shouldn't such letters be part of the informal, behind-the-scenes consultation that often occurs within the executive branch? This is not a simple question to answer, but in some ways public disclosure of prompt letters is a great virtue. Public disclosure promotes transparency and hence accountability. Equally important, public disclosure increases the likelihood that OIRA's concerns will be taken seriously. In the end, agencies remain in charge of their own priorities; but if OIRA's suggestion is reasonable, public disclosure will give agencies an additional reason to investigate it with care.

It would be desirable in this regard for independent groups to play a role in recommending prompt letters. OIRA's own resources are far too limited to enable it to consider all promising possibilities on its own. ${ }^{120}$ Environmental groups, for example, might conduct their own analyses to suggest that new steps ought to be taken to control certain pollutants. Institutions that investigate regulatory issues, and even individual observers from academia and elsewhere, might be provided with a forum by which they could suggest a prompt letter from OIRA. The supporting analysis might be developed privately and reviewed publicly. Steps of this sort might

\footnotetext{
${ }^{118}$ Supra note 108 .

${ }^{119}$ Economic Analysis at EPA, supra note 44.
} 
simultaneously increase the quality of analysis and the level of public participation in the regulatory process.

In our proposed order, we have also given an explicit place to the idea of "return letters." Not only did OIRA announce the use of prompt letters; it also issued four of them. But the practice of returning regulations lay dormant during the last years of the Clinton Administration, ${ }^{121}$ and there is some value in making the power explicit, if only to give a clear signal that it should be exercised in appropriate circumstances.

\section{De Minimis Exceptions, Substitute Risks, Equity, and Distribution}

We have introduced two new principles, implicit in previous orders but deserving explicit recognition. We have also recast the treatment of equity and distributional effects.

1. De Minimis Exceptions. In a series of cases, courts have authorized agencies to exempt trivial risks from regulation, at least when Congress has not unambiguously denied agencies that authority. ${ }^{122}$ This principle is a modern version of an ancient idea: de minimis non curat lex. In the regulatory context, the principle has special importance. When risks are trivial, it is not likely to be worthwhile to eliminate them, partly because the effort distracts attention from more serious problems, partly because of the sheer expense of the effort. We have built the de minimis principle into the executive order, asking agencies not to deal with trivial problems.

2. Substitute Risks. The last decade has seen increasing attention devoted to the possibility that risk regulation will produce substitute risks. ${ }^{123}$ It is well known that fuel economy standards for new cars could result in the production of smaller and less safe vehicles; whatever the extent of this danger, we think it reasonable for government to take steps to avoid it. In the context of the EPA's ozone standard, it was successfully urged that EPA should consider the possibility that regulation of ground-level ozone could actually increase health risks, by

\footnotetext{
${ }^{120}$ See note supra.

121 There were no return letters in the last three years of the Clinton Administration. See John Graham, Presidential Management of the Regulatory State (2001) available at http://www.whitehouse.gov/omb/inforeg/graham_speech121701.html (Dec. 17, 2001).

${ }^{122}$ See, e.g., Ala. Power Co. v. Costle, 636 F. 2d 323, 360-61 (D.C. Cir. 1989) ("Unless Congress has been extraordinarily rigid, there is likely a basis for an implication of de minimis authority to provide exemption when the burdens of regulation yield a gain of trivial or no value.").

${ }^{123}$ See Graham \& Weiner, supra note 18, at 25 (defining the term "risk substitution").
} 
increasing cataracts and skin cancers. ${ }^{124}$ Indeed, courts appear to be creating a new default principle, authorizing agencies to take account of the substitute risks introduced by regulation. The general problem is ubiquitous, and agencies should take corrective steps. We have built into the executive order a specific requirement that agencies attend to the problem.

3. Equity and Distribution. We propose to allow agencies to consider the distributional effects of regulation, and to proceed if an understanding of those effects justifies a departure from the "bottom line" produced by cost-benefit calculations. This is a departure from the Reagan Order, which offered no reference to distributive effects. ${ }^{125}$ At the same time, we require agencies to offer a detailed explanation for proceeding if the costs significantly exceed the benefits. This is a departure from the Clinton Order, which provided somewhat vague references to both "equity" and "distributive impacts." 126 To understand these points, some background is in order.

A conventional objection to cost-benefit analysis is that it treats society as if it were an individual person, and disregards the fact that a regulation typically produces both winners and losers. Suppose, for example, that the costs of stricter controls on particulates are $\$ 500$ million annually, and that the benefits are $\$ 350$ million. Does this mean that the stricter controls are a bad idea? This is not so clear. Skeptics might urge that we need to know far more about the identity of the winners and the losers. Does the $\$ 500$ million cost mean that corporate profits will decline, so that high-level corporate officials will have reduced salaries? Does it mean that prices will increase, and if so, are luxury items involved? Will the $\$ 350$ million in benefits be enjoyed mostly by poor people? By children? Of course a measurement of benefits in terms of "life years" would automatically extend special concern to children. Or by people who are elderly and already well off? Critics of cost-benefit analysis believe that in order to know whether to proceed, it is crucial not simply to tabulate both costs and benefits, but to ask and answer such questions.

Such critics have a point, but there are many complexities here. In some cases, those who benefit from regulation are the same as those who must pay for it, and hence questions of this kind need not arise. The EPA's decision to regulate arsenic in drinking water is a recent

\footnotetext{
${ }^{124}$ See Am. Trucking Ass'n v. EPA, 175 F.3d 1027, 1052 (D.C. Cir. 1999) (discussing the risks of varying levels of stratospheric versus tropospheric ozone).

${ }^{125}$ See Exec. Order No. 12,291, supra note 1.

${ }^{126}$ See Exec. Order No. 12,866, supra note 2
} 
example. ${ }^{127}$ Often, of course, those who gain are not the same as those who lose. But it is wrong to think, as some people seem to do, that regulation typically imposes costs on wealthy corporations and delivers benefits to those in need-and hence that cost-benefit analysis is an unfortunate method for blocking desirable redistribution. The basic reason is that regulation is a crude and often ineffective tool for redistributing resources. ${ }^{128}$ If, for example, high costs are imposed on those who buy automobiles or gasoline, the victims will not be some abstractions called "corporations." On the contrary, it is highly likely that the costs will be felt by some combination of consumers (with price increases being especially hard on the poor), workers who must face lower wages, and people who are thrown into unemployment. And when regulation provides benefits, there is no general reason to think that low-income people will be the beneficiaries. In short, the incidence of regulatory benefits and burdens is not easy to untangle and the burdens are likely to be felt by real people, many of them far from wealthy. All that can be said for certain is that regulation is most unlikely to transfer resources from those who are well off to those who are needy. ${ }^{129}$

Invoking considerations of this kind, some people urge that cost-benefit analysis should be the exclusive basis for regulation, and that equity and distributional effects are all too likely to be used as an all-purpose basis for assistance not to those who are needy, but to powerful private groups. ${ }^{130}$ But we do not favor going so far as to bar consideration of distributive effects. We do believe that the idea of "equity" is too vague to be helpful; but in our view, agencies should be permitted to take account of distributive effects. Certainly they should do so when the context suggests that the benefits will go to people who are especially needy, and that the burdens will be imposed on people who can easily bear them-and also when the burdens would be imposed on the needy and the benefits enjoyed by those who are already very well off. Consider, for example, the fact that poor people have been the disproportionate winners from regulation of air

\footnotetext{
${ }^{127}$ See Cass R. Sunstein, "The Arithmetic of Arsenic," Georgetown Law Journal (?) (forthcoming 2002).

${ }^{128}$ See, e.g., A. Mitchell Polinsky, "An Introduction to Law and Economics," 7-10, 119-120 (1983). and Arrow et al., supra note 9, at 4 ("Too frequently, environmental, health and safety regulation has used a one-size-fits-all or command-control approach.").

${ }^{129}$ Indeed, regulation that is defended on equitable grounds sometimes turns out, in practice, to benefit powerful private groups with no special claim to governmental assistance. See James Hamilton \& W. Kip Viscusi, Calculating Risks 1(2000) (examining "risk measures to cost data to derive estimates of Superfund site remediations" in hazardous waste clean-up projects).

${ }^{130}$ The argument for cost-benefit analysis alone might be supported by noting that a uniform number for mortality and morbidity risks already contains a redistributive element, since it uses the same figure for wealthy and poor
} 
pollution. ${ }^{131}$ Consider also the fact that the burdens of stringent regulation of arsenic in drinking water are likely to be borne disproportionately by those who are relatively less well off. ${ }^{132}$ Though good data will often be absent, agencies should consider effects of this sort.

When the costs are far higher than the benefits, however, agencies should not allow distributive effects to be a kind of all-purpose justification for proceeding. Instead they should give a careful analysis of their approach. We believe that if the costs are grossly disproportionate to the benefits, there should be a strong presumption against regulation, rebuttable only in cases where the distributive argument is compelling.

\section{Requiring Explanation When Benefits Do Not Exceed Costs}

We believe that agencies should generally act only when the benefits exceed the costs. To be sure, this is not meant as a rigid requirement. Agencies should be permitted, in unusual circumstances, to act even when the numbers do not support their action. But in such cases, we ask an agency that chooses to proceed with a regulation that does not pass a cost-benefit test to provide a rationale for doing so. By "does not pass" a benefit-cost test, we mean that the expected quantifiable costs are likely to exceed the quantifiable expected benefits, before taking distributional effects and any other relevant factor into account. Of course there are typically large uncertainties in developing the relevant estimates, and hence a large number of discretionary judgments must be made before generating the numbers. ${ }^{133}$ We think that OIRA administrator should decide when a proposed regulation does not pass a cost-benefit test based on her best judgment. OIRA administrator should be reasonably confident that the quantified net benefits of the proposed regulation are negative before requiring a rationale. For example, a margin on the order of ten million dollars annually could be set as a minimum threshold.

The agency head should be allowed to consider other relevant factors in her decisionmaking, including distributional effects. These factors should be quantified to the extent possible, even if they are not included in the cost-benefit analysis itself. The purpose of the

people--despite the fact that willingness to pay is likely to vary with wealth. Of course, if willingness to pay does vary a narrowly defined cost-benefit analysis would take this into account.

${ }_{131}$ Matthew E. Kahn, The Beneficiaries of Clean Air Act Regulation, 24 Regulation 34 (2001).

132 The arsenic rule provides an interesting case because the problem is often localized. In such cases, several authors have argued for local standards rather than national standards. See, e.g., Jason K. Burnett \& Robert W. Hahn, "A Costly Benefit," 24 Reg. Fall 2001, at 44; William A. Niskanen, "Arsenic and Old Facts," 24 Reg. Fall 2001, at 54 .

${ }^{133}$ See Cass R. Sunstein, The Arithmetic of Arsenic, Geo. L. J. (forthcoming 2002). Arrow et al., supra note, at 6. 
quantification is to make the analysis more transparent. We also believe that factors that cannot be easily be quantified should be factored into the analysis where relevant. In providing the rationale for proceeding, the agency head has an opportunity (and in our view, a duty) to provide a well-reasoned analytical justification for the decision reached. Requiring a rationale for proceeding when expected net benefits are negative will give the regulatory process more legitimacy, and should also lend legitimacy to the use of cost-benefit analysis as a tool for decision making.

Suppose, for example, that a new regulation of a certain air pollutant would have monetized benefits of $\$ 250$ million, but monetized costs of $\$ 280$ million. Suppose, too, that the benefits would come in the form of reduced illnesses among young people, and also reduced mortality effects for people who would otherwise have many additional years. Suppose as well that many of the beneficiaries of the regulation are poor, and that the costs of the regulation would mainly result in higher prices for certain products (say, cars and energy). The problem is not entirely simple, especially because increased energy prices hit poor people hardest; but in this admittedly stylized example, an administrator might well be able to justify a decision to proceed even though the monetized costs exceed the monetized benefits.

\section{E. Make Underlying Analysis Available}

There has been a controversy over public access to data used in regulatory decisionmaking. ${ }^{134}$ The controversy arose when the Environmental Protection Agency finalized a regulation on particulate matter in July of 1997 that gave the agency new power to regulate a variety of emission sources ranging from power plants to lawn mowers and barbecues. The regulation, estimated to cost between 9 and 37 billion annually in 1990 dollars, ${ }^{135}$ was based partly on a study that suggested that reducing emissions of fine particles could lead to substantial reductions in premature mortality. ${ }^{136}$ In response to that controversy, Senator Richard Shelby

\footnotetext{
${ }^{134}$ See Cohen \& Hahn, supra note 99; Science, Technology and Law Program, The National Academies: Seeking Access to Research Data in the 21st Century: An Ongoing Dialogue Among Interested Parties (2001), at http://www4.nas.edu/pd/stl.nsf/web/data_access_workshop/; Michael Gough \& Steven Milloy, The Case for Public Access to Federally Funded Research Data (2000), at http://www.cato.org/pubs/pas/pa-366es.pdf; Angela Antonelli, Public Access to Research Data, Public Comment (1999), at http://www.heritage.org/library/testimony/comment091099.pdf.

${ }_{135}$ Environmental Protection Agency, Regulatory Impact Analysis for the Particulate Matter and Ozone National Ambient Air Quality Standards and Proposed Regional Haze Rule (1997). Arrow et al., supra note, at 6.

${ }^{136}$ See Jocelyn Kaiser, 277 Science 467 (1997).
} 
authored a provision in the 1999 Omnibus Spending Bill that requires data generated under federal awards at universities and non-profit institutions to be available to the public. ${ }^{137}$ OMB then developed a policy to implement the Shelby amendment. ${ }^{138}$

Our recommendation would go further than the Shelby amendment and would require the development of a new policy by OMB. ${ }^{139}$ As a presumption, all relevant information should be made available to the public regarding the derivation of the likely benefits and costs from regulations. ${ }^{140} \mathrm{OMB}$ should address this issue through a policy in its guidelines to the agency (or in a separate policy statement). The primary purpose here is to promote transparency in the regulatory process, so the public and interested parties have better access to information that forms the basis for decision making. ${ }^{141}$

\section{F. Adopt An Annual Regulatory Plan and Retrospective}

If OIRA becomes involved in the process only to approve or reject regulations, it will necessarily have a limited role. It would be highly desirable to create a process by which OIRA, and cost-benefit analysis, become relevant at an early stage. President Reagan attempted to move in this direction with his second executive order, which required agencies to produce an annual regulatory plan. ${ }^{142}$ President Clinton imposed similar requirements, though little was done with them in practice. ${ }^{143}$ A special advantage of this approach is that it promises to increase the authority of agency heads over their staffs, simply by ensuring that plans will be visible before the stage when they are practically final.

Our proposal in this regard is simple and straightforward. We would require every agency to produce an account of its planned rules and to forward that account to OIRA, which would in

\footnotetext{
${ }^{137} \mathrm{Id}$.

${ }^{138}$ OMB Circular A-110, which would permit requesters to be charged a fee for the data. Office of Management and Budget, Circular A-110 (1999), athttp://www.whitehouse.gov/omb/circulars/a110/a110.html.

139 Our recommendation is similar to Hahn and Cohen's recommendation concerning economically significant regulations, but moves beyond federally funded projects. See Cohen \& Hahn, supra note 99.

${ }^{140}$ We are sensitive to the tradeoffs involved in the production of useful information, and, thus, would not require that all information necessarily be provided. For example, companies should not be required to make public proprietary information that would compromise their competitive position. In many cases, however, such data can be presented in a form that does not compromise a particular firm. The matter is somewhat more complicated for scholars. See Linda R. Cohen \& Robert W. Hahn, Should Researchers Be Required to Share Data Used in Supporting Regulatory Decisions? (1999), at http://www.aeibrookings.org/publications/reganalyses/reg_analysis_99_01.pdf.

${ }^{141}$ For very significant decisions, say, involving billions of dollars annually, we think that interested parties should have access not only to data, but also to the models that generate key results.

${ }^{142}$ Exec. Order No. 12,498, supra note 2.
} 
turn be authorized to work with the agency to require compliance with the principles and requirements of the executive order. By calling for OIRA participation, we hope to ensure more coordination at an early stage than was achieved under Presidents Reagan, Bush, and Clinton.

\section{G. Incorporating Independent Agencies}

We have urged that the process of OIRA review should be widened, to include the independent agencies as well as executive agencies and departments. As a matter of policy, the motivation for this suggestion is straightforward. Independent agencies qualify as such not because of the substance of what they do, but because Congress has chosen to limit the President's power to remove their top officials-saying, in the typical formulation, that removal is acceptable only for "inefficiency, neglect of duty, or malfeasance in office." ${ }^{144}$ Many of the most important agencies in government are independent in this sense, including the Federal Communications Commission, the Federal Trade Commission, the National Labor Relations Board, the Food and Drug Administration, and the Consumer Product Safety Commission.

In principle, there is every reason to include independent agencies within the basic structure of an executive order on federal regulation. Indeed, the argument for including such agencies seems no weaker than the argument for including the conventional executive agencies. Moreover, as Table 5 shows, many of these agencies do not routinely quantify the benefits and costs of their proposed regulations, in part because they are not required to do so. If the goal is to ensure more rationality in regulation, and to devote resources to areas where they would do the most good, the independent agencies deserve inclusion no less than others. The real question is one of law, not of policy.

\footnotetext{
${ }^{143}$ See Hahn et al., supra note 4 .

${ }^{144}$ See, e.g., 15 U.S.C. $§ 41$ (1994) (concerning the FTC); 29 U.S.C. § 661(b) (1994) (concerning the Occupational Safety and Health Review Commission).
} 
Table 5: Federal Regulatory Agencies' Efforts to Catalog Benefit and Cost Information ${ }^{145}$

\begin{tabular}{|c|c|c|c|c|}
\hline \multirow{2}{*}{$\begin{array}{l}\text { Agency } \\
\text { V. Executive }\end{array}$} & \multicolumn{3}{|c|}{$\begin{array}{l}\text { Estimates of the Future Benefits and Costs of } \\
\text { New Regulatory Activities }\end{array}$} & \multirow[t]{2}{*}{$\begin{array}{l}\text { Aggregate Estimates of the Benefits } \\
\text { and Costs of Regulatory Activities }{ }^{\mathrm{a}}\end{array}$} \\
\hline & Major Rules ${ }^{b}$ & & $\begin{array}{l}\text { Nonmajor } \\
\text { Actions }^{c}\end{array}$ & \\
\hline Department of Agriculture & Partial & & No evidence & No \\
\hline Department of Commerce ${ }^{\mathrm{d}}$ & Partial & & No evidence & No \\
\hline Department of Energy $^{\mathrm{d}}$ & Partial & & No evidence & No \\
\hline $\begin{array}{l}\text { Department of Housing and Urban } \\
\text { Development }\end{array}$ & Partial & & No evidence & No \\
\hline Environmental Protection Agency & Partial & & Partial & Partial \\
\hline Food and Drug Administration & Partial & & Partial & No \\
\hline $\begin{array}{l}\text { National Highway Traffic Safety } \\
\text { Administration }\end{array}$ & Partial & & Partial & Partial \\
\hline $\begin{array}{l}\text { Occupational Safety and Health } \\
\text { Administration }\end{array}$ & Partial & & Partial & No \\
\hline VI. Independent & & & & \\
\hline $\begin{array}{lll}\text { Commodity } & \text { Futures } & \text { Trading } \\
\text { Commission } & & \end{array}$ & & No & & No \\
\hline $\begin{array}{lll}\text { Consumer } & \text { Product } & \text { Safety } \\
\text { Commission } & & \end{array}$ & & Partial & & No \\
\hline Federal Communications Commission & & No & & No \\
\hline
\end{tabular}

${ }^{145}$ Robert W. Hahn, Reviving Regulatory Reform: Global Perspective 62, tbls.3-11 (2000). 


\begin{tabular}{|l|l|l|l|l|}
\hline $\begin{array}{l}\text { Federal Deposit Insurance } \\
\text { Corporation }\end{array}$ & No & No \\
\hline $\begin{array}{l}\text { Federal Energy Regulatory } \\
\text { Commission }\end{array}$ & & Partial & No \\
\hline Federal Reserve Board & No & No \\
\hline Federal Trade Commission & No & No \\
\hline Nuclear Regulatory Commission & & Partial & No \\
\hline Securities and Exchange Commission & No & No \\
\hline Surface Transportation Board & No & No \\
\hline
\end{tabular}

a. This category does not imply that an agency does not have enough information to estimate aggregate benefits and costs, but rather that an agency does not provide such information. For example, executive agencies may be able to put together a rough calculation of aggregate benefits and costs by compiling regulatory impact analysis estimates.

b. All executive branch agencies are required to prepare regulatory impact analyses for major or economically significant rules. The analyses do not, however, always include comprehensive or complete estimates of benefits and costs. Hence, we characterize them as "partial."

c. Some agencies frequently estimate the benefits and costs of nonmajor actions. Unfortunately, my examination of the nonmajor universe is not exhaustive. Thus, we are not able to describe the size of the subset of nonmajor rules for which agencies have estimated benefits and costs. For other agencies, we have found no evidence that estimates are provided for nonmajor actions.

d. We have relied primarily on Bliley (1997) for this agency.

e. The Surface Transportation Board replaced the Interstate Commerce Commission in 1996. 
Does the President have the legal authority to do what we propose? Though no President has tested the question, both the Department of Justice ${ }^{146}$ and the American Bar Association ${ }^{147}$ have concluded that he does. As a technical matter, the question remains unresolved. In the key case, Humphrey's Executor v. United States, ${ }^{148}$ the Supreme Court upheld the constitutional legitimacy of the "independent" regulatory agencies, but it did not establish what, in particular, "independence" meant. ${ }^{149}$ Nothing in the Court's opinion resolves the question of whether the President has supervisory authority over the independent agencies. As an initial matter, the question is one of statutory interpretation: What authority has Congress given to the President?

We have noted that the members of independent agencies may be removed by the President, not at his will, but only for "inefficiency, neglect of duty, or malfeasance in office." ${ }^{\prime 50}$ What do these terms mean? There are two possible approaches. On a narrow interpretation, the President is allowed to discharge independent agency heads only for grounds entirely unrelated to policy disagreements --in which case the President may not supervise their policy choices. On this interpretation, the President may discharge people for corruption ("malfeasance in office"), for refusing to do their jobs ("neglect of duty"), or for more general dereliction in the sense of gross incompetence, chronic lateness, and the like ("inefficiency"). On this interpretation, application of the executive order to the independent agencies would indeed raise serious statutory questions. A process by which the President monitors such agencies for corruption and dereliction would be one thing; a process by which the President monitors such agencies for what he considers to be sound policy choices would be quite another.

It is also important to take steps to ensure that existing regulations are subject to a process of continuing monitoring and oversight. We do not require any such steps in the proposed order itself, on the ground that they are best imposed by OMB in its general

\footnotetext{
${ }^{146}$ See Peter Shane \& Harold Bruff, The Law of Presidential Power: Cases and Materials 355-58 (1988).

147 See Peter L. Strauss \& Cass R. Sunstein, "The Role of the President and OMB in Informal Rulemaking," 38 Admin. L. Rev. 181, app. (1986) (providing excerpts to this effect from a recommendation by the ABA's Administrative Law Section and from a memorandum from the Assistant Attorney General for the Office of Legal Counsel).

148295 U.S. 602 (1935),

${ }^{149}$ The Court did suggest, in dicta, that there would be a great deal of practical independence, suggesting that the Federal Trade Commission is "independent of executive authority, except in its selection." 295 U.S .at 625. This idea was followed in Borders v. Reagan, 518 F. Supp. 250, 260 (D. D.C. 1981), vacated as moot, 732 F.2d 181 (D.C. Cir. 1982), which involved President Reagan's effort to remove a member of the District of Columbia Judicial Nomination Commission.

${ }^{150}$ See, e.g., 15 U.S.C. § 41; 29 U.S.C. § 661(b).
} 
oversight function. But the key points are that prospective analysis of costs and benefits are often erroneous ${ }^{151}$ and that unanticipated developments can make regulations obsolete, too stringent, or insufficiently stringent. ${ }^{152}$ In order to assist OMB in its task of proposing an annual report of the costs and benefits of regulation, agencies should generate numbers reflecting their estimates of the effects of their own most significant regulations. In addition, a process should be instituted by each agency to give a retrospective analysis of some of its most costly regulations, to see what kinds of effects they are having in actual process. OIRA might work together with the relevant agencies to identify the best candidates for review.

On the other hand, a broader interpretation of the statutory terms would hardly be impossible as a textual matter. The first point is that the narrow interpretation has the disadvantage of raising some unresolved constitutional problems. While the Court has upheld the idea of independent regulatory commissions, ${ }^{153}$ it has never held that Congress can entirely immunize such commissions from presidential oversight. To those who are skeptical of agency independence as a constitutional matter, the narrow interpretation would be extremely troubling and should be avoided if at all possible, so as to avoid a serious constitutional problem. The second point is that the relevant text is susceptible of a broader understanding. What counts as "inefficiency"? What counts as "neglect of duty"? At a minimum, it seems sensible to say that the President is entitled to require the production of documents to ensure that agency officials are acting efficiently and in a way that does not show neglect. ${ }^{154}$ To this extent, procedural incorporation of the independent agencies--to require them to assess both costs and benefits--seems to be on firm ground. And it would be reasonable to go further. If agencies proceed when the benefits do not exceed the costs, they might reasonably be thought to be acting "inefficiently" (pun intended), and in a way that shows a neglect of duty, at least if the decision to proceed is not adequately explained. A broader interpretation does not much stretch the language.

\footnotetext{
${ }^{151}$ See note supra.

152 See the catalogue of the inadequacies of prospective assessments in Bradley Karkkainen. See also Winston Harrington, Richard D. Morgenstern, and Peter Nelson, "On the Accuracy of Regulatory Cost Estimates," Journal of Policy Analysis and Management, Vol. 19, no. 2, 2000, 297-322.

${ }^{153}$ See Humphrey's Executor, supra note 122 (rejecting a presidential removal of a member of the FTC); Mistretta v. US, 488 US 361, 410-12, pn 32-35 (1989).

${ }^{154}$ This point also follows from the Constitution's Opinions in Writing Clause. See U.S. Const., art. $2, \S 2$.
} 
None of this suggests that the President, or OIRA, should be permitted to displace the decisions of the independent regulatory agencies. But it does suggest that a supervisory role, leaving the ultimate decision to those agencies, would be entirely acceptable. To those who are skeptical of this conclusion, it might make sense to create a special, weaker system of oversight for the independent agencies, limited to procedural matters (and hence allowing no room for return letters). But we think that it would be desirable to keep a single system in place for all agencies, retaining the idea that if an independent agency ultimately seeks to issue a regulation notwithstanding OIRA objection, it is entitled to do so. ${ }^{155}$

If our argument seems far-fetched, consider Bowsher v. Synar. ${ }^{156}$ In Bowsher, the Court struck down Congress' effort to delegate discretionary authority to the Comptroller General. ${ }^{157}$ In so doing, the Court held that the Comptroller was unduly subject to congressional control, and thus operated as an agent of Congress, rather than as a genuinely independent agency. ${ }^{158}$ But what made the Comptroller an agent of Congress? The answer is the governing statute, which allows Congress to discharge the Comptroller for "inefficiency," "neglect of duty," or "malfeasance." "159 But on the narrow view, outlined above, these terms do not allow Congress much in the way of authority over the Comptroller. Rejecting the narrow view, the Court described these terms as "very broad" and suggested that they meant that Congress "in effect ... retained control over the execution of the Act...." 160 In the Court's view, these "very broad [terms] ... could sustain removal of a Comptroller General for any number of actual or perceived transgressions of the legislative will." 161

It would be easy, even natural to take the Bowsher Court's interpretation of the terms governing congressional removal of the Comptroller General as authority for the proper interpretation of the terms governing presidential removal of the members of independent regulatory commissions. This is so for a simple reason: the terms are very close, indeed essentially identical. If the interpretation in Bowsher is to apply here, then

\footnotetext{
${ }^{155} \mathrm{We}$ are bracketing here the complex question when and whether the President can ever "block" an agency head's decision. For a good treatment, see Elena Kagan, "Presidential Administration," 114 Harv. L. Rev. 2245, 2328-2331 (2001).

${ }_{156}^{156} 478$ U.S. 714 (1986).

${ }^{157}$ Id. at 734 .

${ }^{158}$ Id. at $727-32$.

${ }^{159}$ Id. at 729, quoting 31 U.S.C. $\$ 703($ e)(1)(B)(ii)-(iv).

${ }^{160} \mathrm{Id}$. at 734 .
} 
the President's authority is also "very broad" and "could sustain removal" for a large number of actual or perceived transgressions of the presidential will. And if this is correct, then the President does, in fact, have a high degree of authority over the policy choices of the independent agencies. And if this is correct, then inclusion of the independent agencies within the executive order is plainly lawful, simply as a statutory matter.

We do not contend that this argument is obviously correct. Because the statutory language appears in different contexts, it would be possible to understand the terms in the Comptroller General Act differently from the terms limiting presidential power over the independent regulatory agencies. Our argument would obviously be strengthened if, as we believe, constitutional objections to genuine "independence" of certain agencies militate against the narrow reading, which would, compared to our reading, restrict presidential control of the agencies. ${ }^{162}$ In light of this background constitutional concern, the authority of Bowsher, and the ambiguity of the statutory text, we believe that incorporation of the independent agencies would be lawful-a conclusion, we reiterate, ${ }^{163}$ that has been firmly supported by both the Department of Justice and the American Bar Association.

\section{H. Judicial Review}

Under Presidents Reagan, Bush, and Clinton, executive orders on federal regulation were solely for the internal management of the executive branch, and they created no rights for judicial enforcement. ${ }^{164}$ If, for example, an agency's regulatory analysis showed that the benefits did not justify the costs, courts were not permitted to consider that fact on judicial review. To be sure, some statutes require attention to both costs and benefits, and when this is so, the agency's analysis of those factors can be challenged as arbitrary. But the process of analysis under the executive orders, and any disagreements within the executive branch, would not be topics for judicial consideration.

\footnotetext{
${ }^{161}$ Id. at 729.

162 See Lawrence Lessig \& Cass R. Sunstein, "The President and the Administration," 94 Colum. L. Rev. 1, 106-08 (1994) (analyzing the constitutional concerns raised by an agency with "complete independence from the President").

${ }^{163}$ See supra notes 139-40.

${ }^{164}$ See, e.g., Exec. Order No. 13,112, 64 Fed. Reg. 6183, 6186 ("This order is intended only to improve the internal management of the executive branch and is not intended to create any right, benefit, or trust responsibility, substantive or procedural, enforceable at law or equity ... against the United States.")
} 
It is not difficult to understand why the executive branch would be skeptical of the idea of judicial intervention. As a general rule, it is not in the interest of the executive branch to increase the authority of the judiciary over executive officers. To be sure, judicial review might solve an agency problem faced by the President if courts could be enlisted to enforce presidential prerogatives against agencies. But the apparent judgment of the executive branch has been that the risks of that course, prominently including losses on appeal, outweigh the advantages.

We have suggested a modest but significant change, slightly compromising the interests of the executive in favor of the interests of the public as a whole. Under our order, judicial review would be available of the materials generated pursuant to the order, but only to the extent that those materials are relevant to the agency's decision under the relevant statute. This proposal would not violate current law; it would merely add to the set of materials that courts examine when testing the question whether the agency has followed the statute or acted arbitrarily. To be sure, this innovation would add materials to the file for judicial review, and in that sense would complicate the judicial task. But it would add little beyond what courts are now considering in the regulatory context. ${ }^{165}$

\section{What Executive Orders Can and Cannot Do: A Cautionary Note}

We believe that a new executive order on federal regulation could do a great deal of good. One reason is the very signal that such an order would send: By virtue of its high visibility, and because of its source (the White House), a new order would suggest a serious commitment, on the part of high-level officials, to improving regulatory outcomes. Another reason is that such an order could embody institutional and substantive reforms that would reduce the problems of shallowness and narrowness. Our central goal has been to ensure that the commitments in previous executive orders are real rather than symbolic, and we believe that the steps suggested here would be helpful in promoting that goal.

An executive order is not, however, a panacea; it is not sufficient for real change, and for some purposes it is not even necessary. With respect to the question of necessity, we have noted that OIRA could move in many of the directions we propose under

\footnotetext{
${ }^{165}$ See, e.g., Chlorine Chemistry Council v. EPA 206 F.3d 1286 (DC Cir 2000) (ruling that chloroform must be treated as a threshold pollutant under the Safe Drinking Water Act).
} 
existing law, including the existing executive order. Indeed, one of our major goals has been to outline the lessons of over two decades of experience with presidential requirements of cost-benefit balancing and to suggest what can be done in response to that experience. If a new executive order does not seem desirable or feasible, we hope that our discussion and our proposed order will have heuristic value, suggesting what should be done even without formal changes. ${ }^{166}$ With respect to the insufficiency of a new order, some statutes ban cost-benefit balancing, and the executive must obey the law. A thoroughgoing reform effort would require legislative reforms, not merely executive action. At the executive level itself, everything depends on implementation. It is possible that an executive order, like a Constitution, will be a mere "parchment barrier," ${ }^{, 167}$ with little or no effect on the real world. In fact, successful implementation probably requires high-level political support, in the form, for example, of a clear understanding that the President or the Vice President is committed to the process inaugurated by the executive order. But an executive order would itself be a step toward establishing that understanding.

To make the process truly effective, however, greater congressional support will probably be required. This support will only come if the public sees a need for greater transparency and accountability in the regulatory process. The reality is that most of the public is (usually rationally) uninformed on many regulatory issues, including the issue of regulatory oversight. ${ }^{168}$ And legislators do not typically have a strong incentive to support regulatory reforms that promote accountability. Indeed, many members of Congress seem to prefer to pass laws and regulations that give the appearance of fixing the problem-leaving it to the executive and the judiciary to sort out implementation. ${ }^{169}$ Without stronger congressional efforts, any steps from the President will have a limited effect.

\footnotetext{
${ }^{166}$ Note in this regard that prompt letters and return letters are being issued in significant numbers without any formal changes. See Prompt Letters, supra note 108; Return Letters, at http://www.whitehouse.gove/omb/inforeg/return_letter.html (archiving recent return letters).

${ }^{167}$ Jack N. Rakove, Parchment Barriers and the Politics of Rights, in A Culture of Rights: The Bill of Rights in Philosophy, Politics, and Law--1791 and 1991 98, 129-36 (Michael J. Lacey \& Knud Haakonssen eds., 1991).

${ }^{168}$ For the classic discussion of rational ignorance on the part of voters, see, e.g., Anthony Downs, An Economic Theory of Democracy (1957),

${ }^{169}$ On the political economy of regulation, see e.g., Roger G. Noll, Reforming Regulation (1971); Bruce M. Owen \& Ronald Braeutigam, The Regulation Game (1978); Roger Noll, The Economics and Politics of the Slowdown in Regulatory Reform (1999), available at http://www.aei.brookings.org/publications/books/economics_and_politics.pdf.
} 


\section{Conclusion}

Government regulation continues to display a pattern of "paranoia and neglect." ${ }^{170}$ Understood as a pragmatic tool for drawing attention to the likely effects of regulation, cost-benefit analysis holds out considerable promise for overcoming the underlying problems. For over twenty years, executive orders have attempted to discipline the administrative process by requiring agencies to pay close attention to both costs and benefits. But the overall record is mixed. In many cases, cost-benefit analysis does appear to have improved agency decisions in quite significant ways. ${ }^{171}$ At the same time, the system for OIRA review has not succeeded in fundamentally redirecting regulation toward areas where it would do the most good.

Of course there are many reasons for this mixed record. ${ }^{172}$ But part of the reason, we suggest, is that the executive's commitment to cost-benefit analysis remains both too shallow and too narrow. It is too shallow because too much of the time agencies fail to take the commitment seriously, and the process of OIRA review has not ensured that they will do so. It is too narrow because a large number of agencies are not subject to OIRA review at all. We have suggested a range of possible responses. To overcome shallowness, we have called for mandatory compliance with OMB guidelines on regulatory analysis; formalized the ideas of "return letters" and "prompt letters;" offered new principles governing substitute risks and trivial risks; clarified the issue of equity and distributional effects; and authorized limited judicial review of the materials generated through this process. To overcome narrowness, we have included the independent agencies, which issue many of the nation's most important regulations, within the scope of the order.

As we have discussed, an executive order, standing by itself, will not do all, or even nearly all, of what should be done. A great deal depends on personnel and on a serious commitment, on the part of high-level officials, to regulatory reform. Congressional support is also important. As we have emphasized, such a commitment could accomplish a great deal, building on what we have suggested here, under the

\footnotetext{
${ }^{170}$ John D. Graham, Making Sense of Risk: An Agenda for Congress, in Risks, Costs, and Lives Saved 183, 183 (Robert W. Hahn ed., 1996).

${ }^{171}$ See Economic Analysis at EPA, supra note 44.

${ }^{172}$ One reason, mentioned above, is that Congress sometimes bans cost-benefit balancing. See Whitman $v$. American Trucking Ass'n, 531 U.S. 457, 471 (2001) (holding that the Clean Air Act "unambiguously bars cost considerations" when the EPA sets ambient air quality standards under the Act).
} 
existing executive order; and to reduce the reality and appearance of partisanship, there are clear advantages to a situation in which an administration of one party is operating under principles laid down under an administration of another party. But the experience of the last two decades suggests that a revised and improved executive order could attract the support of people with a wide range of political commitments, and inaugurate significant improvements in the system of government regulation. 


\section{Appendix A New Executive Order}

The American people deserve a regulatory system that protects and improves their health, safety, environment, and well-being without imposing unacceptable or unreasonable costs on society. Regulatory policies should be based on a careful assessment of the likely consequences of regulation, including an effort to assess and balance both costs and benefits. Regulatory policies should use the lowest-cost means of achieving social goals. Public and private resources should be devoted to large problems, not trivial ones. The general objective of this Executive Order is to ensure that cost-benefit analysis, understood as a tool to produce better decisions, will have a far larger role in the federal government than it now does. The particular objectives are: to ensure that regulations are adopted on the basis of an evaluation of their likely consequences; to promote sensible priority-setting; to increase attention to neglected problems while reducing expenditures on minor or nonexistent problems; to ensure that agencies consider alternatives to costly regulation; to enhance planning and coordination with respect to both new and existing regulations; and to make the process accessible and open to the public. In pursuing these objectives, the regulatory process shall be conducted so as to meet applicable statutory requirements and with due regard to the discretion that has been entrusted to the Federal agencies.

Accordingly, by the authority vested in me as President by the Constitution and the laws of the United States of America, it is hereby ordered as follows:

\section{SECTION 1. STATEMENT OF REGULATORY APPROACH AND REQUIREMENTS}

(A) Approach. Federal agencies should promulgate only those regulations that are required by law, are necessary to interpret the law, or are made necessary by compelling public need, such as material failures of private markets to protect or improve the health and safety of the public, the environment, or the well-being of the American people. In deciding whether and how to regulate, agencies shall assess the costs and benefits of reasonable regulatory alternatives, including the alternative of not regulating. Costs and benefits shall be understood to include both quantifiable measures (to the fullest extent that these can be usefully estimated) and qualitative measures of costs and benefits that are difficult to quantify, but nevertheless essential to consider. Agencies should ordinarily 
act only if the incremental benefits exceed the incremental costs. Further, in choosing among alternative regulatory approaches, agencies should ordinarily select the approach that maximizes net benefits, unless a statute requires another regulatory approach.

(B) Agency Requirements. To ensure that agency regulations are consistent with the approach set forth above, agencies shall adhere to the following requirements, to the extent permitted by law:

(1) Each agency shall identify the problem that it intends to address as well as assess the significance of that problem.

(2) Each agency shall explain why the problem that it intends to address is not adequately handled by private markets or by state or local authorities.

(3) Each agency shall examine whether existing regulations (or other law) have created, or contributed to, the problem that a new regulation is intended to correct and whether those regulations (or other law) should be modified to achieve the intended goal of regulation more effectively.

(4) Each agency shall identify and assess available alternatives to direct regulation, including providing economic incentives to encourage the desired behavior, such as user fees or marketable permits, or providing information upon which choices can be made by the public.

(5) In setting regulatory priorities, each agency shall attempt to ensure that it addresses serious problems rather than trivial ones and shall consider, to the extent reasonable, the degree and nature of the risks posed by various substances or activities within its jurisdiction.

(6) Each agency shall explore and explain whether any regulation will create significant new risks of any kind, and if so, shall identify the extent of any new risks in qualitative and quantitative terms.

(7) When an agency determines that a regulation is the best available method of achieving the regulatory objective, it shall design its regulation in the most cost-effective manner to achieve that objective.

(8) Each agency shall assess both the incremental costs and benefits of the intended regulation and, recognizing that some costs and benefits are uncertain and difficult to quantify, should generally propose or adopt a regulation only upon a reasoned determination that the incremental benefits of the intended regulation exceed its 
incremental costs. If an agency determines to proceed even though the quantifiable incremental benefits do not exceed the quantifiable incremental costs, then the agency should explain why it intends to proceed in those circumstances, by, for example, referring to distributional effects as authorized by subsection (15) below.

(9) Each agency shall base its decisions on the best reasonably obtainable scientific, economic, and other information concerning the need for, and consequences of, the intended regulation.

(10) Each agency shall identify and assess reasonable alternative forms of regulation, including at least two reasonable alternatives to the option under consideration, one more stringent and one less stringent.

(11) Each agency shall, to the extent feasible, use performance objectives, rather than specifying the behavior or manner of compliance that regulated entities must adopt.

(12) Wherever feasible, agencies shall seek the views of those most likely to be affected, including appropriate state, local, and tribal officials before imposing regulatory requirements that might significantly or uniquely affect those governmental entities. As appropriate, agencies shall seek to reduce unnecessary conflicts between federal regulatory actions and other law and regulation, including that issued by state and local governments.

(13) Each agency shall avoid regulations that are inconsistent, incompatible, or duplicative with/of other regulations or policies.

(14) Each agency shall draft its regulations in language that is simple and easy to understand.

(15) Each agency shall consider, as appropriate, distributional effects, and after undertaking the analysis of costs and benefits, agencies shall be permitted to take account of those distributional effects in deciding whether to proceed. If the costs exceed the benefits by a substantial margin, agencies shall proceed only if the distributional effects are very clear and highly desirable.

\section{SECTION 2. ORGANIZATION}

An efficient regulatory planning and review process is vital to ensure that the Federal Government's regulatory system best serves the American people. 
(A) The Office of Management and Budget. Coordinated review of agency rulemaking is necessary to ensure that regulations are consistent with applicable law, the President's priorities, and the principles set forth in this Executive Order, and that decisions made by one agency do not conflict with the policies or actions taken or planned by another agency. The Office of Management and Budget (OMB) shall carry out that review function. Within OMB, the Office of Information and Regulatory Affairs (OIRA) is the repository of expertise concerning regulatory issues and should thus take the lead in implementing this Executive order. Where appropriate, OIRA should draw heavily on the expertise of the Council of Economic Advisers and the Office of Science and Technology Policy in developing sound regulatory policy. To the extent permitted by law, OMB shall provide guidance to agencies and assist the President, the Vice President, and other regulatory policy advisors to the President in regulatory planning, and shall be the entity that reviews individual regulations, as provided by this Executive order.

(B) OIRA shall be authorized to review proposed regulations. To carry out this task, OIRA shall issue guidelines governing regulatory impact analyses. These guidelines shall be issued after an appropriate period for comments from affected agencies, the private sector, and any interested persons. When a proposed regulation does not, in OIRA's view, conform to the principles set out in this Executive Order or to OIRA guidelines for engaging in regulatory analysis, OIRA shall return the regulation to the agency for reconsideration.

(C) OIRA shall be authorized to prompt agencies to undertake actions where the incremental benefits exceed the incremental costs. When OIRA has asked an agency to undertake such action, the agency shall, within 60 days, offer a public account of its intended course of action.

(D) The Vice President. The Vice President is the principal advisor to the President on, and shall coordinate the development and presentation of recommendations concerning, regulatory policy, planning, and review, as set forth in this Executive Order. In fulfilling their responsibilities under this Executive Order, the President and the Vice President may be assisted by the regulatory policy advisors within the Executive Office of the 
President and by such agency officials and personnel as the President and the Vice President may, from time to time, consult.

\section{SeCTION 3. DeFINITIONS}

For purposes of this Executive order:

(A) "Advisors" refers to regulatory policy advisors consulted by the President and Vice President, including, among others: the Director of OMB; the Chair (or another member) of the Council of Economic Advisers; the Assistant to the President for Economic Policy; the Assistant to the President for Domestic Policy; the Assistant to the President for National Security Affairs; the Assistant to the President for Science and Technology; the Assistant to the President for Intergovernmental Affairs; the Assistant to the President and Staff Secretary; the Assistant to the President and Chief of Staff to the Vice President; the Assistant to the President and Counsel to the President; the Deputy Assistant to the President and Director of the White House Office on Environmental Policy; and the Administrator of OIRA, who also shall coordinate communications relating to this Executive order among the agencies, OMB, the other Advisors, and the Office of the Vice President.

(B) "Agency," unless otherwise indicated, means any authority of the United States that is an "agency" under 44 U.S.C. § 3502(1), including those considered to be independent regulatory agencies, as defined in 44 U.S.C. $\S 3502(10)$.

(C) "Director" means the Director of OMB.

(D) "Regulation" or "rule" means an agency statement of general applicability and future effect, which the agency intends to have the force and effect of law, that is designed to implement, interpret, or prescribe law or policy or to describe the procedure or practice requirements of an agency. It does not, however, include:

(1) Regulations or rules that pertain to a military or foreign affairs function of the United States, other than procurement regulations and regulations involving the import or export of non-defense articles and services;

(2) Regulations or rules that are limited to agency organization, management, or personnel matters; or 
(3) Any other category of regulations exempted by public notice of the Administrator of OIRA.

(E) "Regulatory action" means any substantive action by an agency (normally published in the Federal Register) that promulgates or is expected to lead to the promulgation of a final rule or regulation, including notices of inquiry, advance notices of proposed rulemaking, and notices of proposed rulemaking.

(F) "Significant regulatory action" means any regulatory action that is likely to result in a rule that may:

(1) Have an annual effect on the economy of $\$ 100$ million or more or adversely affect in a material way the economy, the environment, public health or safety;

(2) Create a serious inconsistency or otherwise interfere with an action taken or planned by another agency; or

(3) Materially alter the budgetary impact of entitlements, grants, user fees, or loan programs or the rights and obligations of recipients thereof.

\section{SECTION 4. CENTRALIZED REVIEW OF REGULATIONS}

The guidelines set forth below shall apply to all regulatory actions, for both new and existing regulations, by agencies other than those agencies specifically exempted by public notice of the Administrator of OIRA:

(A) Agency Responsibilities. In addition to adhering to its own rules and procedures and to the requirements of applicable law, each agency shall develop its regulatory actions in a timely fashion and adhere to the following procedures with respect to a regulatory action:

(a) Each agency shall provide OIRA, at such times and in the manner specified by the Administrator of OIRA, with a list of its planned regulatory actions, indicating those which the agency believes are subject to review under this Executive order. Absent a material change in the development of the planned regulatory action, those not designated as significant will not be subject to review under this section unless, within 10 working days of receipt of the list, the Administrator of OIRA notifies the agency that OIRA has determined that a planned regulation is a significant regulatory 
action within the meaning of this Executive Order. The Administrator of OIRA may by public notice waive review of any planned regulatory action designated by the agency as significant, in which case the agency need not further comply with subsection $(A)(2)(b)$ or subsection $(A)(2)(c)$ of this section.

(b) For each matter identified as, or determined by the Administrator of OIRA to be, a significant regulatory action, the issuing agency shall provide to OIRA:

(i) The text of the draft regulatory action, together with a reasonably detailed description of the need for the regulatory action and an explanation of how the regulatory action will meet that need. The description of need should clearly identify whether the regulation is designed to address a specific failure in the functioning of markets and how it addresses that need.

(ii) An assessment of the potential costs and benefits of the regulatory action, including an explanation of the manner in which the regulatory action is consistent with a statutory mandate and, to the extent permitted by law, maximizes net economic benefits.

(c) For those matters identified as, or determined by the Administrator of OIRA to be, a significant regulatory action within the scope of section $3(F)(1)$, the agency shall also provide to OIRA the following additional information developed as part of the agency's decision-making process (unless prohibited by law):

(i) An assessment, including the underlying analysis, of benefits anticipated from the regulatory action together with, to the extent feasible, a quantification of those benefits.

(ii) An assessment, including the underlying analysis, of costs anticipated from the regulatory action, together with, to the extent feasible, a quantification of those costs; and

(iii) An assessment, including the underlying analysis, of costs and benefits of potentially effective and reasonably feasible alternatives to the planned regulation-including improvements to the current regulation and viable nonregulatory actions such as information provision-and an explanation why the planned regulatory action is preferable to the identified potential alternatives. 
(d) In emergency situations, or when an agency is obligated by law to act more quickly than normal review procedures allow, the agency shall notify OIRA as soon as possible and, to the extent practicable, comply with subsections (A)(2)(b) and (c) of this section. For those regulatory actions that are governed by a statutory or courtimposed deadline, the agency shall, to the extent practicable, schedule rulemaking proceedings so as to permit sufficient time for OIRA to conduct its review, as set forth below in subsection (B)(2) through (4) of this section.

(e) After the regulatory action has been published in the Federal Register or otherwise issued to the public, the agency shall:

(i) Make available to the public, via the Internet and through other appropriate means, the information set forth in subsections $(A)(2)(B)$ and $(A)(2)(C)$;

(ii) Identify for the public, in a complete, clear, and simple manner, the substantive changes between the draft submitted to OIRA for review and the action subsequently announced; and

(iii) Identify for the public those changes in the regulatory action that were made at the suggestion or recommendation of OIRA.

(B) OIRA Responsibilities. The Administrator of OIRA shall provide meaningful guidance and oversight so that each agency's regulatory actions are consistent with applicable law, the President's priorities, and the principles set forth in this Executive Order and do not conflict with the policies or actions of another agency. OIRA shall, to the extent permitted by law, adhere to the following guidelines:

(1) OIRA shall review all actions identified by the agency or by OIRA as significant regulatory actions.

(2) OIRA shall waive review or notify the agency in writing of the results of its review within the following time periods:

(a) For any notices of inquiry, advance notices of proposed rulemaking, or other preliminary regulatory actions prior to a Notice of Proposed Rulemaking, within 10 working days after the date of submission of the draft action to OIRA; 
(b) For all other regulatory actions, within 90 calendar days after the date of submission of the information required by this Order, unless OIRA has previously reviewed this information and, since that review, there has been no material change in the facts and circumstances upon which the regulatory action is based, in which case, OIRA shall complete its review within 60 days; and

(c) The review process may be extended either (1) once by no more than 30 calendar days upon the written approval of the Director or (2) at the request of the agency head.

(3) For each regulatory action that the Administrator of OIRA returns to an agency for further consideration of some or all of its provisions, the Administrator of OIRA shall provide the issuing agency a written explanation for such return, setting forth the pertinent provision of this Executive Order on which OIRA is relying.

(4) For each regulatory action for which the Administrator of OIRA issues a prompt letter, the Administrator of OIRA shall provide the issuing agency a written explanation for such prompt, setting forth the pertinent provision of this Executive Order on which OIRA is relying.

(5) Except as otherwise provided by law or required by a Court, in order to ensure greater openness, accessibility, and accountability in the regulatory review process, OIRA shall be governed by the following disclosure requirements:

(a) All substantive communications between OIRA personnel and persons not employed by the executive branch of the Federal Government regarding a regulatory action under review shall be governed by the following guidelines:

(i) A representative from the issuing agency shall be invited to any meeting between OIRA personnel and such person(s);

(ii) OIRA shall forward to the issuing agency, within 10 working days of receipt of the communication(s), all written communications, regardless of format, between OIRA personnel and any person who is not employed by the executive branch of the Federal Government, and the dates and names of individuals involved in all substantive oral communications (including meetings to which an agency representative was invited, but did not attend, and telephone conversations between OIRA personnel and any such persons); and 
(iii) OIRA shall publicly disclose relevant information about such communication(s), as set forth below.

(b) OIRA shall maintain a publicly available log that shall contain, at a minimum, the following information pertinent to regulatory actions under review:

(i) The status of all regulatory actions, (ii) A notation of all written communications forwarded to an issuing agency; and

(iii) The dates and names of individuals involved in all substantive oral communications, including meetings and telephone conversations, between OIRA personnel and any person not employed by the executive branch of the Federal Government, and the subject matter discussed during such communications.

(c) After the regulatory action has been published in the Federal Register or otherwise issued to the public, or after the agency has announced its decision not to publish or issue the regulatory action, OIRA shall make available to the public all documents exchanged between OIRA and the agency during the review by OIRA under this section. Provided, that OIRA shall make exceptions to ensure protection of material that is proprietary or otherwise privileged.

\section{SECTION 5: REGULATORY RETROSPECTIVE AND REGULATORY PLANNING}

(A) Each agency shall produce an annual report on the benefits and costs of its significant regulations during the past year. A draft of the annual report shall be submitted to OIRA to ensure an adequate period (in no case less than ninety days) for OIRA review and comment.

(B) Each agency shall produce, by December 31 of each year, a report on its planned activities for the following year ("annual regulatory plan"). OIRA shall be given an opportunity to comment on the annual regulatory plan and to work with the relevant agency to ensure compliance with the requirements and principles in this order.

\section{SECTION 6. RESOLUTION OF CONFLICTS}

To the extent permitted by law, disagreements or conflicts between or among agency heads, or between OIRA and any agency, that cannot be resolved by the Administrator of 
OIRA shall be resolved by the President, or by the Vice President acting at the request of the President, with the relevant agency head (and, as appropriate, other interested government officials). Vice Presidential and Presidential consideration of such disagreements may be initiated only by the Director, by the head of the issuing agency, or by the head of an agency that has a significant interest in the regulatory action at issue. Such review will not be undertaken at the request of other persons, entities, or their agents.

Resolution of such conflicts shall be informed by recommendations developed by the Vice President, after consultation with the Advisors (and other executive branch officials or personnel whose responsibilities to the President include the subject matter at issue). The development of these recommendations shall be concluded within 60 days after review has been requested.

At the end of this review process, the President, or the Vice President acting at the request of the President, shall notify the affected agency and the Administrator of OIRA of the President's decision with respect to the matter.

\section{SECTION 7. PUBLICATION}

Except to the extent required by law, an agency shall not publish in the Federal Register or otherwise issue to the public any regulatory action that is subject to review under section 4 of this Executive Order until whichever of the following occurs first:

(1) the Administrator of OIRA notifies the agency that OIRA has waived its review of the action or has completed its review without any requests for further consideration; or

(2) the applicable time period expires without OIRA having notified the agency that it is returning the regulatory action for further consideration. If the terms of the preceding sentence have not been satisfied and an agency wants to publish or otherwise issue a regulatory action, the head of that agency may request Presidential consideration through the Vice President, as provided under section 6 of this Order. Upon receipt of this request, the Vice President shall notify OIRA and the Advisors. The guidelines and 
time period set forth in this Order shall apply to the publication of regulatory actions for which Presidential consideration has been sought.

\section{SECTION 8. JUDICIAL REVIEW}

This Executive order is intended to improve the internal management of the Federal Government. Agency analyses generated by this Executive order shall be placed on file for judicial review and, to the extent that those analyses are relevant to the legality of the agency's conduct, the reviewing court may consider them in assessing the legal issues. This Executive order does not otherwise create any right or benefit, substantive or procedural, enforceable at law or equity by a party against the United States, its agencies or instrumentalities, its officers or employees, or any other person.

Readers with comments should address them to:

Cass R. Sunstein

University of Chicago Law School

1111 East 60th Street

Chicago, IL 60637 


\section{Chicago Working Papers in Law and Economics}

(Second Series)

1. William M. Landes, Copyright Protection of Letters, Diaries and Other Unpublished Works: An Economic Approach (July 1991)

2. Richard A. Epstein, The Path to The T. J. Hooper: The Theory and History of Custom in the Law of Tort (August 1991)

3. Cass R. Sunstein, On Property and Constitutionalism (September 1991)

4. Richard A. Posner, Blackmail, Privacy, and Freedom of Contract (February 1992)

5. Randal C. Picker, Security Interests, Misbehavior, and Common Pools (February 1992)

6. Tomas J. Philipson \& Richard A. Posner, Optimal Regulation of AIDS (April 1992)

7. Douglas G. Baird, Revisiting Auctions in Chapter 11 (April 1992)

8. William M. Landes, Sequential versus Unitary Trials: An Economic Analysis (July 1992)

9. William M. Landes \& Richard A. Posner, The Influence of Economics on Law: A Quantitative Study (August 1992)

10. Alan O. Sykes, The Welfare Economics of Immigration Law: A Theoretical Survey With An Analysis of U.S. Policy (September 1992)

11. Douglas G. Baird, 1992 Katz Lecture: Reconstructing Contracts (November 1992)

12. Gary S. Becker, The Economic Way of Looking at Life (January 1993)

13. J. Mark Ramseyer, Credibly Committing to Efficiency Wages: Cotton Spinning Cartels in Imperial Japan (March 1993)

14. Cass R. Sunstein, Endogenous Preferences, Environmental Law (April 1993)

15. Richard A. Posner, What Do Judges and Justices Maximize? (The Same Thing Everyone Else Does) (April 1993)

16. Lucian Arye Bebchuk and Randal C. Picker, Bankruptcy Rules, Managerial Entrenchment, and Firm-Specific Human Capital (August 1993)

17. J. Mark Ramseyer, Explicit Reasons for Implicit Contracts: The Legal Logic to the Japanese Main Bank System (August 1993)

18. William M. Landes and Richard A. Posner, The Economics of Anticipatory Adjudication (September 1993)

19. Kenneth W. Dam, The Economic Underpinnings of Patent Law (September 1993)

20. Alan O. Sykes, An Introduction to Regression Analysis (October 1993)

21. Richard A. Epstein, The Ubiquity of the Benefit Principle (March 1994)

22. Randal C. Picker, An Introduction to Game Theory and the Law (June 1994)

23. William M. Landes, Counterclaims: An Economic Analysis (June 1994)

24. J. Mark Ramseyer, The Market for Children: Evidence from Early Modern Japan (August 1994)

25. Robert H. Gertner and Geoffrey P. Miller, Settlement Escrows (August 1994)

26. Kenneth W. Dam, Some Economic Considerations in the Intellectual Property Protection of Software (August 1994)

27. Cass R. Sunstein, Rules and Rulelessness, (October 1994)

28. David Friedman, More Justice for Less Money: A Step Beyond Cimino (December 1994) 
29. Daniel Shaviro, Budget Deficits and the Intergenerational Distribution of Lifetime Consumption (January 1995)

30. Douglas G. Baird, The Law and Economics of Contract Damages (February 1995)

31. Daniel Kessler, Thomas Meites, and Geoffrey P. Miller, Explaining Deviations from the Fifty Percent Rule: A Multimodal Approach to the Selection of Cases for Litigation (March 1995)

32. Geoffrey P. Miller, Das Kapital: Solvency Regulation of the American Business Enterprise (April 1995)

33. Richard Craswell, Freedom of Contract (August 1995)

34. J. Mark Ramseyer, Public Choice (November 1995)

35. Kenneth W. Dam, Intellectual Property in an Age of Software and Biotechnology (November 1995)

36. Cass R. Sunstein, Social Norms and Social Roles (January 1996)

37. J. Mark Ramseyer and Eric B. Rasmusen, Judicial Independence in Civil Law Regimes: Econometrics from Japan (January 1996)

38. Richard A. Epstein, Transaction Costs and Property Rights: Or Do Good Fences Make Good Neighbors? (March 1996)

39. Cass R. Sunstein, The Cost-Benefit State (May 1996)

40. William M. Landes and Richard A. Posner, The Economics of Legal Disputes Over the Ownership of Works of Art and Other Collectibles (July 1996)

41. John R. Lott, Jr. and David B. Mustard, Crime, Deterrence, and Right-to-Carry Concealed Handguns (August 1996)

42. Cass R. Sunstein, Health-Health Tradeoffs (September 1996)

43. G. Baird, The Hidden Virtues of Chapter 11: An Overview of the Law and Economics of Financially Distressed Firms (March 1997)

44. Richard A. Posner, Community, Wealth, and Equality (March 1997)

45. William M. Landes, The Art of Law and Economics: An Autobiographical Essay (March 1997)

46. Cass R. Sunstein, Behavioral Analysis of Law (April 1997)

47. John R. Lott, Jr. and Kermit Daniel, Term Limits and Electoral Competitiveness: Evidence from California State Legislative Races (May 1997)

48. Randal C. Picker, Simple Games in a Complex World: A Generative Approach to the Adoption of Norms (June 1997)

49. Richard A. Epstein, Contracts Small and Contracts Large: Contract Law through the Lens of Laissez-Faire (August 1997)

50. Cass R. Sunstein, Daniel Kahneman, and David Schkade, Assessing Punitive Damages (with Notes on Cognition and Valuation in Law) (December 1997)

51. William M. Landes, Lawrence Lessig, and Michael E. Solimine, Judicial Influence: A Citation Analysis of Federal Courts of Appeals Judges (January 1998)

52. John R. Lott, Jr., A Simple Explanation for Why Campaign Expenditures are Increasing: The Government is Getting Bigger (February 1998)

53. Richard A. Posner, Values and Consequences: An Introduction to Economic Analysis of Law (March 1998)

54. Denise DiPasquale and Edward L. Glaeser, Incentives and Social Capital: Are Homeowners Better Citizens? (April 1998) 
55. Christine Jolls, Cass R. Sunstein, and Richard Thaler, A Behavioral Approach to Law and Economics (May 1998)

56. John R. Lott, Jr., Does a Helping Hand Put Others At Risk?: Affirmative Action, Police Departments, and Crime (May 1998)

57. Cass R. Sunstein and Edna Ullmann-Margalit, Second-Order Decisions (June 1998)

58. Jonathan M. Karpoff and John R. Lott, Jr., Punitive Damages: Their Determinants, Effects on Firm Value, and the Impact of Supreme Court and Congressional Attempts to Limit Awards (July 1998)

59. Kenneth W. Dam, Self-Help in the Digital Jungle (August 1998)

60. John R. Lott, Jr., How Dramatically Did Women Suffrage Change the Size and Scope of Government? (September 1998)

61. Kevin A. Kordana and Eric A. Posner, A Positive Theory of Chapter 11 (October 1998)

62. David A. Weisbach, Line Drawing, Doctrine, and Efficiency in the Tax Law (November 1998)

63. Jack L. Goldsmith and Eric A. Posner, A Theory of Customary International Law (November 1998)

64. John R. Lott, Jr., Public Schooling, Indoctrination, and Totalitarianism (December 1998)

65. Cass R. Sunstein, Private Broadcasters and the Public Interest: Notes Toward A AThird Way@January 1999)

66. Richard A. Posner, An Economic Approach to the Law of Evidence (February 1999)

67. Yannis Bakos, Erik Brynjolfsson, Douglas Lichtman, Shared Information Goods (February 1999)

68. Kenneth W. Dam, Intellectual Property and the Academic Enterprise (February 1999)

69. Gertrud M. Fremling and Richard A. Posner, Status Signaling and the Law, with Particular Application to Sexual Harassment (March 1999)

70. Cass R. Sunstein, Must Formalism Be Defended Empirically? (March 1999)

71. Jonathan M. Karpoff, John R. Lott, Jr., and Graeme Rankine, Environmental Violations, Legal Penalties, and Reputation Costs (March 1999)

72. Matthew D. Adler and Eric A. Posner, Rethinking Cost-Benefit Analysis (April 1999)

73. John R. Lott, Jr. and William M. Landes, Multiple Victim Public Shooting, Bombings, and Right-to-Carry Concealed Handgun Laws: Contrasting Private and Public Law Enforcement (April 1999)

74. Lisa Bernstein, The Questionable Empirical Basis of Article 2 Incorporation Strategy: A Preliminary Study (May 1999)

75. Richard A. Epstein, Deconstructing Privacy: and Putting It Back Together Again (May 1999)

76. William M. Landes, Winning the Art Lottery: The Economic Returns to the Ganz Collection (May 1999) 
77. Cass R. Sunstein, David Schkade, and Daniel Kahneman, Do People Want Optimal Deterrence? (June 1999)

78. Tomas J. Philipson and Richard A. Posner, The Long-Run Growth in Obesity as a Function of Technological Change (June 1999)

79. David A. Weisbach, Ironing Out the Flat Tax (August 1999)

80. Eric A. Posner, A Theory of Contract Law under Conditions of Radical Judicial Error (August 1999)

81. David Schkade, Cass R. Sunstein, and Daniel Kahneman, Are Juries Less Erratic than Individuals? Deliberation, Polarization, and Punitive Damages (September 1999)

82. Cass R. Sunstein, Nondelegation Canons (September 1999)

83. Richard A. Posner, The Theory and Practice of Citations Analysis, with Special Reference to Law and Economics (September 1999)

84. Randal C. Picker, Regulating Network Industries: A Look at Intel (October 1999)

85. Cass R. Sunstein, Cognition and Cost-Benefit Analysis (October 1999)

86. Douglas G. Baird and Edward R. Morrison, Optimal Timing and Legal Decisionmaking: The Case of the Liquidation Decision in Bankruptcy (October 1999)

87. Gertrud M. Fremling and Richard A. Posner, Market Signaling of Personal Characteristics (November 1999)

88. Matthew D. Adler and Eric A. Posner, Implementing Cost-Benefit Analysis When Preferences Are Distorted (November 1999)

89. Richard A. Posner, Orwell versus Huxley: Economics, Technology, Privacy, and Satire (November 1999)

90. David A. Weisbach, Should the Tax Law Require Current Accrual of Interest on Derivative Financial Instruments? (December 1999)

91. Cass R. Sunstein, The Law of Group Polarization (December 1999)

92. Eric A. Posner, Agency Models in Law and Economics (January 2000)

93. Karen Eggleston, Eric A. Posner, and Richard Zeckhauser, Simplicity and Complexity in Contracts (January 2000)

94. Douglas G. Baird and Robert K. Rasmussen, Boyd Legacy and Blackstone Ghost (February 2000)

95. David Schkade, Cass R. Sunstein, Daniel Kahneman, Deliberating about Dollars: The Severity Shift (February 2000)

96. Richard A. Posner and Eric B. Rasmusen, Creating and Enforcing Norms, with Special Reference to Sanctions (March 2000)

97. Douglas Lichtman, Property Rights in Emerging Platform Technologies (April 2000)

98. Cass R. Sunstein and Edna Ullmann-Margalit, Solidarity in Consumption (May 2000)

99. David A. Weisbach, An Economic Analysis of Anti-Tax Avoidance Laws (May 2000)

100. Cass R. Sunstein, Human Behavior and the Law of Work (June 2000)

101. William M. Landes and Richard A. Posner, Harmless Error (June 2000) 
102. Robert H. Frank and Cass R. Sunstein, Cost-Benefit Analysis and Relative Position (August 2000)

103. Eric A. Posner, Law and the Emotions (September 2000)

104. Cass R. Sunstein, Cost-Benefit Default Principles (October 2000)

105. Jack Goldsmith and Alan Sykes, The Dormant Commerce Clause and the Internet (November 2000)

106. Richard A. Posner, Antitrust in the New Economy (November 2000)

107. Douglas Lichtman, Scott Baker, and Kate Kraus, Strategic Disclosure in the Patent System (November 2000)

108. Jack L. Goldsmith and Eric A. Posner, Moral and Legal Rhetoric in International Relations: A Rational Choice Perspective (November 2000)

109. William Meadow and Cass R. Sunstein, Statistics, Not Experts (December 2000)

110. Saul Levmore, Conjunction and Aggregation (December 2000)

111. Saul Levmore, Puzzling Stock Options and Compensation Norms (December 2000)

112. Richard A. Epstein and Alan O. Sykes, The Assault on Managed Care: Vicarious Liability, Class Actions and the Patient Bill of Rights (December 2000)

113. William M. Landes, Copyright, Borrowed Images and Appropriation Art: An Economic Approach (December 2000)

114. Cass R. Sunstein, Switching the Default Rule (January 2001)

115. George G. Triantis, Financial Contract Design in the World of Venture Capital (January 2001)

116. Jack Goldsmith, Statutory Foreign Affairs Preemption (February 2001)

117. Richard Hynes and Eric A. Posner, The Law and Economics of Consumer Finance (February 2001)

118. Cass R. Sunstein, Academic Fads and Fashions (with Special Reference to Law) (March 2001)

119. Eric A. Posner, Controlling Agencies with Cost-Benefit Analysis: A Positive Political Theory Perspective (April 2001)

120. Douglas G. Baird, Does Bogart Still Get Scale? Rights of Publicity in the Digital Age (April 2001)

121. Douglas G. Baird and Robert K. Rasmussen, Control Rights, Priority Rights and the Conceptual Foundations of Corporate Reorganization (April 2001)

122. David A. Weisbach, Ten Truths about Tax Shelters (May 2001)

123. William M. Landes, What Has the Visual Arts Rights Act of 1990 Accomplished? (May 2001)

124. Cass R. Sunstein, Social and Economic Rights? Lessons from South Africa (May 2001)

125. Christopher Avery, Christine Jolls, Richard A. Posner, and Alvin E. Roth, The Market for Federal Judicial Law Clerks (June 2001)

126. Douglas G. Baird and Edward R. Morrison, Bankruptcy Decision Making (June 2001)

127. Cass R. Sunstein, Regulating Risks after ATA (June 2001)

128. Cass R. Sunstein, The Laws of Fear (June 2001) 
129. Richard A. Epstein, In and Out of Public Solution: The Hidden Perils of Property Transfer (July 2001)

130. Randal C. Picker, Pursuing a Remedy in Microsoft: The Declining Need for Centralized Coordination in a Networked World (July 2001)

131. Cass R. Sunstein, Daniel Kahneman, David Schkade, and Ilana Ritov, Predictably Incoherent Judgments (July 2001)

132. Eric A. Posner, Courts Should Not Enforce Government Contracts (August 2001)

133. Lisa Bernstein, Private Commercial Law in the Cotton Industry: Creating Cooperation through Rules, Norms, and Institutions (August 2001)

134. Richard A. Epstein, The Allocation of the Commons:Parking and Stopping on the Commons (August 2001)

135. Cass R. Sunstein, The Arithmetic of Arsenic (September 2001)

136. Eric A. Posner, Richard Hynes, and Anup Malani, The Political Economy of Property Exemption Laws (September 2001)

137. Eric A. Posner and George G. Triantis, Covenants Not to Compete from an Incomplete Contracts Perspective (September 2001)

138. Cass R. Sunstein, Probability Neglect: Emptions, Worst Cases, and Law (November 2001)

139. Randall S. Kroszner and Philip E. Strahan, Throwing Good Money after Bad? Board Connections and Conflicts in Bank Lending (December 2001)

140. Alan O. Sykes, TRIPs, Pharmaceuticals, Developing Countries, and the Doha ASolution@February 2002)

141. Edna Ullmann-Margalit and Cass R. Sunstein, Inequality and Indignation (February 2002)

142. Daniel N. Shaviro and David A. Weisbach, The Fifth Circuit Gets It Wrong in Compaq v. Commissioner (February 2002) (Published in Tax Notes, January 28, 2002)

143. Warren F. Schwartz and Alan O. Sykes, The Economic Structure of Renegotiation and Dispute Resolution in the WTO/GATT System (March 2002, forthcoming Journal of Legal Studies 2002)

144. Richard A. Epstein, HIPAA on Privacy: Its Unintended and Intended Consequences (March 2002, forthcoming Cato Journal, summer 2002)

145. David A. Weisbach, Thinking Ouside the Little Boxes (March 2002, forthcoming Texas Law Review)

146. Eric A. Posner, Economic Analysis of Contract Law after Three Decades: Success or Failure (March 2002)

147. Randal C. Picker, Copyright as Entry Policy: The Case of Digital Distribution (April 2002, forthcoming The Antitrust Bulletin)

148. David A. Weisbach, Taxes and Torts in the Redistribution of Income (April 2002, Coase Lecture February 2002)

149. Cass R. Sunstein, Beyond the Precautionary Principle (April 2002)

150. Robert W. Hahn and Cass R. Sunstein, A New Executive Order for Improving Federal Regulation? Deeper and Wider Cost-Benefit Analysis (April 2002) 